\title{
Divergent Approaches to Virulence in C. albicans and C. glabrata: Two Sides of the Same Coin
}

\author{
Mónica Galocha ${ }^{1,2}\left(\right.$, Pedro Pais ${ }^{1,2} \oplus$, Mafalda Cavalheiro ${ }^{1,2}$, Diana Pereira ${ }^{1,2}$, \\ Romeu Viana ${ }^{1,2}$ (D) and Miguel C. Teixeira ${ }^{1,2, *(\mathbb{D})}$ \\ 1 Department of Bioengineering, Instituto Superior Técnico, Universidade de Lisboa, \\ 1049-001 Lisboa, Portugal; monicagalocha@gmail.com (M.G.); pedrohpais@tecnico.ulisboa.pt (P.P.); \\ mafalda.cavalheiro@tecnico.ulisboa.pt (M.C.); diana.pereira@tecnico.ulisboa.pt (D.P.); \\ romeuviana@outlook.com (R.V.) \\ 2 iBB-Institute for Bioengineering and Biosciences, Biological Sciences Research Group, Instituto Superior \\ Técnico, University of Lisbon, Av. Rovisco Pais, 1049-001 Lisboa, Portugal \\ * Correspondence: mnpct@tecnico.ulisboa.pt; Tel.: +351-218417772; Fax: +351-218419199
}

Received: 10 April 2019; Accepted: 8 May 2019; Published: 11 May 2019

check for updates

\begin{abstract}
Candida albicans and Candida glabrata are the two most prevalent etiologic agents of candidiasis worldwide. Although both are recognized as pathogenic, their choice of virulence traits is highly divergent. Indeed, it appears that these different approaches to fungal virulence may be equally successful in causing human candidiasis. In this review, the virulence mechanisms employed by $C$. albicans and C. glabrata are analyzed, with emphasis on the differences between the two systems. Pathogenesis features considered in this paper include dimorphic growth, secreted enzymes and signaling molecules, and stress resistance mechanisms. The consequences of these traits in tissue invasion, biofilm formation, immune system evasion, and macrophage escape, in a species dependent manner, are discussed. This review highlights the observation that C. albicans and C. glabrata follow different paths leading to a similar outcome. It also highlights the lack of knowledge on some of the specific mechanisms underlying C. glabrata pathogenesis, which deserve future scrutiny.
\end{abstract}

Keywords: Candida; host-pathogen interaction; virulence; biofilm formation; morphology; immune evasion

\section{Introduction}

Infections caused by fungi affect millions of people worldwide, with the overall mortality rate estimated to be roughly 1,350,000 deaths per year [1]. Among pathogenic fungi, Candida species are responsible for the most common invasive fungal disease in developed countries-the candidiasis [2]. Candida species live as commensals on mucosal surfaces where they are constituents of the normal microbiota of the oral cavity and gastrointestinal and vaginal tracts. However, they can opportunistically become pathogenic under suitable conditions, such as host-disrupted microbiota or immunocompromised hosts, being responsible for clinical manifestations from mucocutaneous overgrowth to bloodstream infections [3-5]. Of the various Candida species, Candida albicans and Candida glabrata not only account for $60 \%$ of Candida species present in the human body, but also constitute the most prevalent of the pathogenic Candida species, being responsible for more than 400,000 life-threatening infections worldwide every year [3,6].

C. albicans and C. glabrata are the two most common pathogenic yeasts of humans, yet they are phylogenetically, genetically, and phenotypically very different. On one hand, C. albicans diploid genome carries several gene families that are associated with virulence [7]. These include the ALS (agglutinin-like sequence) adhesins, required for host adhesion, secreted aspartyl proteases 
(SAPs) and phospholipases, which allow for the degradation of host barriers and the invasion of surrounding tissue, and proteins involved in oligopeptide and iron transfer [8-10]. On the other hand, C. glabrata mechanisms of tissue invasion are mostly unknown, although it is hypothesized to possibly occur by endocytosis induction of host cells [11]. Its haploid genome encodes a large group of glycosylphosphatidylinositol (GPI)-anchored cell wall proteins, such as the adhesins from the EPA gene family, implicated in fungus-host interactions or biofilm formation, and a family of aspartic proteases (yapsins) which are mainly associated with cell wall remodeling and possible immune evasion $[12,13]$. Moreover, key virulence attributes of $C$. albicans, which are known to be the basis of its pathogenicity, are absent in C. glabrata [14]. Switching from yeast to hyphal growth not only allows consistent biofilm production but also enables $C$. albicans to be highly invasive and escape macrophage engulfment [15-19]. Nevertheless, both species are known to use biofilms to colonize the surface of several medical devices based on different materials [20]. Unlike C. albicans, it has been demonstrated that $C$. glabrata lets itself be taken up by macrophages, where it persists and divides for long periods of time eventually leading to cell lysis due to fungal load [21,22]. It has the ability of detoxifying oxidative radical species and disrupting normal phagosomal maturation, leading to the inhibition of phagolysosome formation and phagosome acidification [21,23].

The interaction between Candida and its host cells is characterized by a complex interplay between the expression of fungal virulence factors and the host immune system, and the presence of other microorganisms affects this interplay. This review aims to explore and compare the remarkably distinct paths toward virulence trailed by the two most common causative agents of candidiasis worldwide. On one hand, C. albicans is known for its ability to evade host defenses and form bulk biofilms due to its ability to undergo filamentous growth, while on the other hand, C. glabrata is an unusually stress-tolerant organism able to survive and replicate inside the immune system cells. Despite having such distinct virulence features, C. glabrata and C. albicans are frequently co-isolated [11].

\section{Host Damage and Invasion}

There is a variety of defense mechanisms through which the human host is able to prevent invasion by pathogenic microorganisms, such as C. albicans and C. glabrata. These mechanisms consist not only of physical but also of chemical barriers. For instance, epithelial cells, which in most cases are the first line of contact between host and pathogen, function as the prime physical barrier restraining Candida from invasion of the underlying tissue. On one hand, these cells are interconnected through "tight junctions" preventing the entry of microorganisms into interepithelial space and eventually into the bloodstream [24,25]. On the other hand, some types of epithelial cells, such as those in the intestinal or vaginal epithelium, are able to produce a mucus layer by secreting mucins [24,26]. This layer impairs Candida invasion by preventing contact with the epithelium surface. Likewise, in the oral cavity the flow of saliva plays an important role as both a physical and a chemical barrier as it not only prevents the adhesion to mucosa and dental surfaces but also contains several antimicrobial agents that impair the contact of Candida with the oral epithelium [27,28]. Another chemical barrier against Candida establishment is the presence of gastric acid and bile in the digestive system which creates a harsh environment for fungal growth. Nevertheless, these human pathogens are known to have a remarkable ability to adapt to these adverse conditions and proliferate.

C. albicans relies on two distinct invasion mechanisms to gain entry into host cells: (i) induced endocytosis and (ii) active penetration of hyphal forms through physical forces of hyphae production associated with lytic enzyme secretion [29] (Figure 1). Nonetheless, depending on the host cell, these invasion mechanisms are thought to be exploited to a different extent. For instance, it was demonstrated that while invasion into oral epithelial cells occurs via both routes, invasion into intestinal epithelial cells occurs only via active penetration under normal conditions [29,30]. 


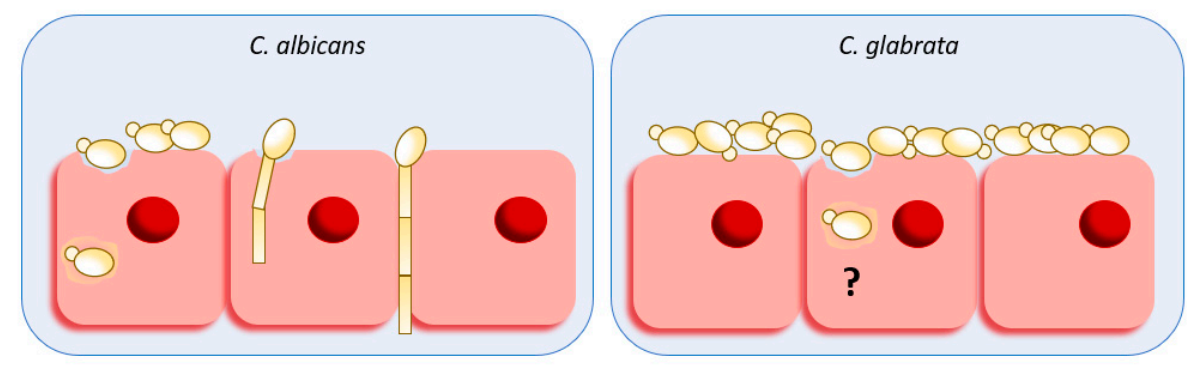

Figure 1. Schematic representation of C. albicans and C. glabrata host damage and invasion. C. albicans enter host cells through induced endocytosis or by active penetration (inter- and intra-cellular) of hyphal forms associated with the release of hydrolytic enzymes, resulting in the damage of cells and loss of epithelial integrity. Induced endocytosis of host cells is thought to be the mechanism behind C. glabrata tissue invasion.

Living within host cells is a profitable strategy since it enables cells to deal with the host immune system and antimicrobial treatment, and there are plenty of nutrients available and an absence of competition with other commensal microorganisms. Additionally, dissemination into deeper tissues and ultimately into the bloodstream is easier from within the cell. Fungal invasion via induced endocytosis is dependent on dynamic microfilaments of the host. In C. albicans, the GPI-anchored hypha-associated protein Als3 interacts with mammalian cadherins, mimicking the establishment of adherence junctions. This process leads to rearrangements in the actin cytoskeleton that ultimately lead to fungal cell internalization [31]. Similarly, Ssa1, a member of the HPS70 heat shock protein family, was reported to play the same role as Als3, being essential for maximal host cell damage and subsequently fungal cell endocytosis [32]. However, EED1 was the first fungal gene reported as being required for epithelial escape and interepithelial dissemination and not for initial invasion into epithelial cells [33]. Moreover, it is thought that the contact with the epithelium, among several other stimuli, is a highly potent inducer of $C$. albicans filamentation. In turn, the contact between hyphal cells and epithelial cells induces host defense mechanisms such as the formation of epithelial cell protrusions surrounding the hyphae, and membrane ruffling, which is characteristic for induced endocytosis [34].

The ability to switch between yeast and hyphal growth forms is one of the most discussed and best-investigated virulence attributes of C. albicans. This morphology switch is activated by well-established kinase-based signal transduction pathways and is triggered by diverse host environmental cues, including temperature, $\mathrm{pH}$, serum, and $\mathrm{CO}_{2}$ and is linked to several steps during host invasion [35,36]. The extracellular signals are transmitted via Ras to both protein kinase A and the MAP kinase cascade [37-39], inducing hyphal differentiation through the activation of a number of transcription factors such as Efg1 [40] and Ume6 [41]. The transcriptional repressor Nrg1 is inactivated and removed from the hyphal-specific gene promoters, thereby allowing the induction of hyphal morphogenesis [42,43].

Invasion into epithelial cells via active penetration relies on a combination of physical pressure employed by the growing hyphae and the secretion of hydrolytic enzymes. Moreover, hyphal cells are capable of directional growth in response to contact with a solid surface (thigmotropism) which enables C. albicans to specifically identify and invade intercellular junctions, thereby damaging the epithelium compact structure [44]. Interestingly, it was very recently discovered that C. albicans release hydroxyphenylacetic acid (HPA) during hyphal growth [45]. Its production seems to occur through the same pathway and the same precursors as tyrosol, which is able to stimulate hypha induction in C. albicans [46], therefore their biological functions are likely to be the same. Additionally, along with the active penetration by hyphal cells, there is also the secretion of hydrolytic enzymes, such as SAPs and phospholipases, which can digest epithelial cell surface components enabling the entrance into or between host cells [47]. SAPs are the best-characterized members of the C. albicans hydrolytic enzymes, as is well reviewed by Hube and Naglik [48]. Interestingly, these tissue damaging 
enzymes not only have distinct optimal $\mathrm{pH}$ requirements but also are growth stage and infection site related [47]. For instance, SAP1-SAP3 are yeast growth-associated and have optimum activity at lower $\mathrm{pH}$ values, while SAP4-SAP6 are hyphal growth-associated and have optimum activity at higher $\mathrm{pH}$ values [49]. Similarly, it was demonstrated that $S A P 1, S A P 3$, and SAP8 are preferentially expressed in vaginal, rather than oral, C. albicans infections [47]. One possible explanation for the existence of a significant number of different $S A P$ genes may be the necessity for specific and optimized proteinases during the different stages of an infection [48]. Additionally, the cytolytic peptide toxin of $C$. albicans candidalysin, encoded by the hypha-associated gene ECE1, was recently found to be essential for damage of enterocytes and is a key factor in subsequent fungal translocation, suggesting that transcellular translocation of C. albicans through intestinal layers is mediated by candidalysin [25]. Moreover, phytase activity in C. albicans was demonstrated to be important for virulence. Phytate is a major storage form of phosphorus in plants and is abundant in the human diet and intestinal tract [50]. Recently, it was reported that decreased phytase activity leads to a reduced ability to form hyphae, attenuated in vitro adhesion, and reduced ability to penetrate human epithelium [51].

While the transition from yeast to hyphae has been extensively studied in C. albicans, the switch from hyphae to yeast still remains poorly understood [35]. Nevertheless, both yeast and hyphae forms are found in infection sites, which suggests that both forms are implicit in the infection process. Interestingly, it was demonstrated that depending on the infected organ, one or the other morphology predominates [52]. It is thought that the yeast form is important for dissemination upon infection, whereas hyphae forms are more relevant to attachment, host invasion, and tissue damage [53].

Unlike C. albicans, and despite the existence of some reports demonstrating that $C$. glabrata forms pseudohyphae $[54,55]$, the pathogenicity of $C$. glabrata seems to be independent of morphology. The most common route for this pathogen to reach the bloodstream is through the iatrogenic breach of natural barriers, such as the use of catheters, trauma, or surgery.

In 2000, Csank and Haynes [54] reported for the first time that C. glabrata can undergo morphological change and grow as a pseudohyphae on solid nitrogen starvation media. This invasive growth mode could be a possible mechanism of host invasion, however, this phenomenon has not yet been reported in vivo. Despite lacking this prime virulence feature, this opportunistic pathogen is still able to reach the human bloodstream and cause infection. In some cases, C. glabrata can involuntarily reach the bloodstream through nosocomial conditions, namely surgery, catheter, parenteral nutrition, and burn injury [56]. However, even when these external factors are abrogated, C. glabrata is able to invade the host and colonize different tissues, as shown in an intragastrointestinal mouse model of infection [57] and in a chorioallantoic membrane chicken embryo model of infection [58]. Thus, C. glabrata must have other invasion mechanisms.

Co-infection with other microorganisms may be a possible explanation to the invasive capacity of C. glabrata since this yeast is often co-isolated in infections with C. albicans [59-61] or even other pathogens such as Clostridium difficile [62]. In the co-infected environment, C. glabrata cells may exploit the tissue invasion and destruction caused by $C$. albicans to access nutrients and reach the bloodstream. In fact, Tati et al. (2016) [63] demonstrated that when mice are infected with C. glabrata alone, oropharyngeal candidiasis is negligible, however, when co-infected with C. albicans, an increased colonization by C. glabrata was observed. This effect was attributed to the binding of $C$. glabrata to C. albicans hyphae [63] and similar results were reported by Alves et al. (2014) [64] using a reconstituted human vaginal epithelium. Nonetheless, the intracytoplasmic presence of C. glabrata was detected in oral epithelial cells [65] and vaginal epithelial cells [66] and it has been shown that when endocytosis is inhibited, the internalization of C. glabrata is prevented [65]. This suggests that induced endocytosis by host cells could be the most likely mechanism of $C$. glabrata internalization (Figure 1).

As referred to before, the tissue/cell damaging ability of C. glabrata is lower compared to C. albicans. In C. albicans, secreted hydrolytic enzymes are considered to be important destructive factors that damage host tissues, providing nutrients for its propagation. However, the production of these hydrolytic enzymes is very low or even null in C. glabrata, wherefore its importance for virulence does 
not seem to be as relevant as it is in C. albicans [67-73]. The proteinase enzyme is responsible for protein degradation resulting in tissue invasion. Among the proteases, SAPs are considered crucial for the pathogenicity of C. albicans [74]. Although C. glabrata does not express SAPs [75], its genome contains 11 non-secreted GPI-linked aspartyl proteases (YPS genes), which are surface-exposed aspartic proteases required for virulence, known as yapsins [13]. These yapsins are important for cell wall maintenance, remodeling, cell to cell interactions, and resistance to cell wall stress, however, their direct link with virulence is not very well characterized yet. Otherwise, phospholipases promote the destruction of cell membrane phospholipids, causing cell damage and lysis which allows a greater invasive capacity [76]. Some of the C. glabrata strains are able to produce these enzymes $[67,68,70,71,77]$, which appear to play a role in C. glabrata-associated persistent candidemia [9]. However, phospholipase production in C. glabrata is lower than in C. albicans, and in some cases inexistent $[69,72,73]$, therefore its relation to C. glabrata virulence is not clear and needs further analysis.

\section{Adhesion and Biofilm Formation}

The ability to infect and prevail in the human host is related to different pathogenesis factors, of which biofilm formation excels [19,78-80]. Candida species ability to form biofilms on medical devices increases mortality rates associated with infections, while often forcing the treatment to include the removal of the medical device [81]. A lot of efforts have been put into understanding the molecular basis of Candida species biofilm formation [20].

Adhesion is one of the most relevant and advantageous capacities of the yeast cell wall. It allows cells to colonize mucosal surfaces and prevail in a nutritional environment, being the first critical step for biofilm formation, which serves as a shield against adverse conditions, as well as a highly drug-resistant reservoir of infective cells $[82,83]$. C. albicans and C. glabrata pathogenesis has been strongly related to adhesion, which is considered a crucial virulence factor in these yeasts [84-86]. In this regard, both Candida species are able to not only attach to mammalian host cells (epithelial, endothelial, and immune cells) but also to other microbes (bacteria and other Candida species) and abiotic surfaces, such as medical devices $[85,87]$. Several studies have tried to understand the nature of adherence to plastic surfaces. For instance, cell surface hydrophobicity (CSH) seems to have a positive correlation with adhesion in both C. albicans and C. glabrata species, thus, adhesion is mediated by van der Waals forces. Moreover, compared to C. albicans, the relative CSH of C. glabrata has been shown to be significantly higher [88-90].

Both Candida species have a set of proteins that enable attachment, known as adhesins. The most important C. albicans adhesins are agglutinin-like sequence (Als) proteins (Als1-7 and Als9) [91] and hypha-associated GPI-linked protein (Hwp1), known to be required for adhesion and virulence in vivo, and also being associated to biofilm formation through interaction with Als1 and Als3 adhesins [92-94]. Other adhesins required for adhesion and biofilm formation include Hwp2 [95] and Eap1 [96-98]. C. glabrata expresses a large group of adhesins, belonging to the epithelial adhesin (Epa) family, which is encoded by 17 to 23 genes, depending on the strain [78]. Among these, Epa1 is a major virulence player in C. glabrata, and mediates $95 \%$ of in vitro adhesion to epithelial cells [99]. This adhesin is highly heterogeneous among C. glabrata clinical isolates, being an important virulence factor [100]. Epa6 and Epa7 are involved in kidney and bladder colonization in vivo and boost biofilm formation [101-104]. Transcriptomic and proteomic studies have revealed that besides EPA genes, C. glabrata holds other biofilm-related adhesin families, such as Pwp (encoded by seven members PWP1-7), Aed (AED1 and AED2), and Awp (encoded by 12 members AWP1-6 and AWP8-13), which are usually found in significantly higher numbers in clinical isolates, consistently with an important role in pathogenesis [12,105-107].

The successful pathogenicity of these yeasts relies on its flexibility, which allows for adaptation and proliferation under both nutrient-rich and nutrient-poor conditions. Several studies have reported the importance of host and antifungal selective pressure on virulence traits as adhesion [108,109]. A recent study conducted by Vale-Silva et al. (2017) [110] used the PacBio technology to compare the genomes 
of two sequential C. glabrata clinical isolates and observed a significant increase in the number of adhesin-encoding genes (101 and 107) when compared to the CBS138 genome (63), despite the limited variation between the two studied isolates. The same authors, along with Ni et al. (2018) [111], further linked the increased expression of the adhesin gene EPA1 with gain-of-function (GOF) mutations in the PDR1 gene in drug-resistant clinical isolates [112]. EPA1 has been strongly related to adhesion of C. glabrata cells to mammalian epithelial cells both in vitro [99] and in vivo [113]. Furthermore, Salazar et al. (2018) [114] also observed a GOF mutation in the PDR1 gene, which led to changes in the transcriptome when compared to the CBS138 strain. Among the genes identified as having the highest number of non-synonymous SNPs, there were several genes encoding adhesins and, agreeing with Vale-Silva et al. (2013) [115], the number of adhesin-expressed genes varied when compared to other GOF PDR1 mutations [114]. This reinforces the idea that antifungal treatment deploys a tight selective pressure which results in changes at the genomic and transcriptional levels, particularly affecting adhesin-encoding genes [116]. The transcription factor Cst6 was found to also play a role in C. glabrata adhesion and biofilm formation, negatively regulating the expression of EPA6 [103]. In C. albicans, a transcriptional regulatory network comprising nine regulators (Bcr1, Brg1, Efg1, Flo8, Gal4, Ndt80, Rob1, Rfx2, and Tec1) was identified in in vitro and in vivo studies as underlying the biofilm formation phenomenon in this pathogenic yeast [117-121].

Hyphae formation, which is exclusive to C. albicans, when compared to C. glabrata is also an important trait in biofilm development. Various studies have described hyphae as exhibiting improved adhesion to the human epithelium, with these cells displaying increased expression of Als1, Als3, and Hwp1 [122-125]. Interestingly, Tati et al. (2016) [63] characterized the co-colonization of C. glabrata and C. albicans in a murine model of oropharyngeal candidiasis (OPC) and demonstrated that this is driven by specific adhesins in both species. Namely, the C. albicans Als3 and Als1 adhesins are crucial for in vitro binding of C. glabrata cells to C. albicans hyphae and for further in vivo establishment of infection. Considering C. glabrata cells, incubation with C. albicans hyphae led to the overexpression of the adhesins EPA8, EPA19, AWP2, AWP7, and CAGLOF00181 [63].

After adhesion, Candida species are known to be able to form a 3D-structure of cells embedded in a gel-like matrix $[20,126,127]$. In order to achieve this, surface-adhered cells begin to adhere to other Candida cells, initiating the formation of discrete colonies, which correspond to an early phase of biofilm formation. At this point, the intermediate phase begins with the cellular production and secretion of important molecules, known as extracellular polymeric substances (EPS), that will constitute the extracellular matrix of the biofilm, protecting the cells and ensuring a more developed 3D-structure. The final structure is reached after the maturation phase, where more cells and the matrix are originated. Mature biofilms might also suffer the detachment of some cells that can spread to form new biofilms on other niches of the host, a process called the dispersal phase $[20,126,128,129]$. Although this process is true for every Candida species, there are differences between C. albicans and C. glabrata biofilms, regarding their dimensions and structure, cell morphology, EPS produced and secreted, response to environmental cues, and resistance to antifungal drugs (Figure 2).

A very clear difference between C. albicans and C. glabrata mature biofilms is the dimension and total biomass of each biofilm. C. glabrata in vivo biofilm formation leads to a thickness of 75-90 $\pm 5 \mu \mathrm{m}$, which is half of the normal thickness of C. albicans biofilms [130], with much less biomass in the end of biofilm formation compared to C. albicans [131]. The organization of the biofilm structure also differs between these two species. C. albicans biofilms are arranged in a three-dimensional structure with different morphologies and empty spaces between cells [132], where microchannels are formed [133]. On the other hand, C. glabrata biofilms are thinner, but display a higher density of cells, tightly packed together [132]. Although C. glabrata's biofilms are composed by yeast cells only [131,132], the same is not true for $C$. albicans biofilms, where different morphologies arise. C. albicans mature biofilms are composed by a dense network of pseudohyphae, hyphae, and yeast cells [134]. This filamentation process in biofilm formation is controlled by the transcription factor Efg1, without which C. albicans only forms scarce monolayers of elongated yeast cells on polyurethane catheters and polystyrene $[135,136]$. 

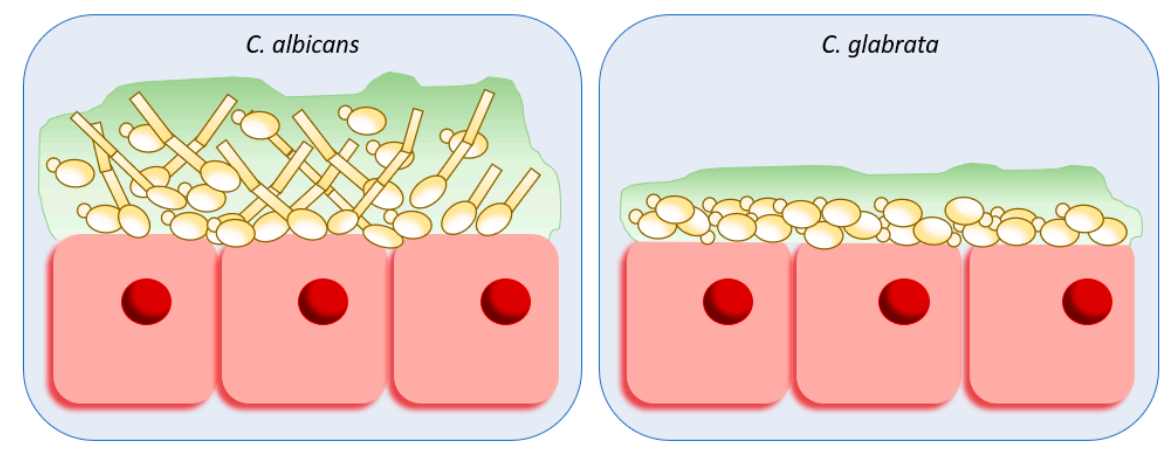

Figure 2. Schematic representation of C. albicans and C. glabrata biofilm formation. C. albicans forms thicker biofilms, with much more biomass in the end of biofilm formation and produces more extracellular matrix than C. glabrata. C. albicans mature biofilms are composed by a dense network of pseudohyphae, hyphae, and yeast cells, whereas C. glabrata biofilms are composed by compact yeast cells only, forming a thin but dense biofilm.

Although C. albicans produces more extracellular matrix than C. glabrata [137], the main components of the matrix, proteins, and carbohydrates, are the same in both biofilms [131,138-140]. Interestingly, C. glabrata has a very high content of proteins and carbohydrates, which is five times higher than that found on the biofilms of other non-albicans Candida species [131]. C. albicans' matrix is also composed by other lipids (mainly neutral glycerolipids, polar glycerolipids, and a small percentage of sphingolipids) [139], phosphorus, and uronic acid [140]. Biofilms of both species also have a small content of extracellular DNA [131,138-140].

Interestingly, C. albicans and C. glabrata also behave differently on different surfaces when it comes to initiating biofilm formation. Cleary, each species has a different propensity to form biofilm on a given surface. For instance, $C$. albicans is known to adhere better to latex and silicone elastomer while showing less biofilm formation on polyvinyl chloride, polyurethane, or $100 \%$ silicone [134]. C. albicans also adheres and forms biofilm on different surfaces of denture base materials, having higher biofilm formation on the surface of alloy and lower biofilm formation on methacrylate-based denture material [141]. Moreover, polyetherurethane treated with $6 \%$ of polyethylene oxide was found to reduce the metabolic activity of cells and the total biomass of $C$. albicans biofilms [142]. On the other hand, while all other pathogenic Candida species have greater biofilm formation on Teflon, C. glabrata prefers polyvinyl chloride to form biofilm [143]. Interestingly, other components of the environment might alter the ability of Candida species to adhere to a given surface. For instance, the presence of saliva has been shown to decrease the ability of C. albicans to form biofilm in vitro [144,145].

Depending on the antifungal drug, C. albicans and C. glabrata biofilms might be able to resist the therapeutic action of the drug. For instance, Choi and colleagues (2007) [146] measured the in vitro susceptibilities of biofilms of C. glabrata and C. albicans bloodstream isolates, showing that both biofilms were resistant to fluconazole and only moderately resistant to amphotericin B, while exposure to 0.25 to $1 \mu \mathrm{g} / \mathrm{mL}$ of caspofungin and micafungin lead to an $80 \%$ reduction of the biofilms. Moreover, voriconazole is also able to reduce C. albicans and C. glabrata biofilms, being present at $0.25 \mathrm{mg} / \mathrm{L}$ or being used as a surface coating at different concentrations [147]. Nevertheless, when growing on an RPMI 1640 medium, C. glabrata mature biofilms have shown to be less susceptible to caspofungin and anidulafungin than C. albicans mature biofilms on a polystyrene surface [148], showing that each species biofilms might resist differently to the same antifungal drug. Although reacting differently to antifungal drug exposure, the strategy to achieve resistance seems to be very similar between the two species. The mechanisms known to underlie resistance to antifungal drugs in Candida biofilms are believed to be related to alterations in the metabolic activity, the role of the extracellular matrix as a barrier for diffusion, the role of its EPS components, and the presence of persister cells within the biofilm $[20,149]$. Both species suffer the upregulation of drug efflux pump-encoding genes [138,150], as well as seem to rely on the $\beta$-1,3-glucans present on the extracellular matrix [151,152]. 
Biofilms also allow for the survival of Candida species by protecting them against the host immune system. The extracellular matrix is essential for the protection against the action of neutrophils by inhibiting the release of neutrophil extracellular traps (NETs) [153]. Moreover, the $\beta$-glucans present on the matrix avoid the activation of neutrophils, actually inhibiting the reactive oxygen response, thereby being an important distracting mechanism to evade the innate immune system [154]. Biofilms are also believed to resist well the action of the innate immune system due to its heterogenicity, given the different types of cells and different metabolic activity the cells might present on biofilms [155].

The combination of $C$. albicans and C. glabrata to form biofilm has been well described and the two species are usually found together in niches of candidiasis patients [60]. A recent study has shown that a ratio of $C$. albicans to $C$. glabrata of 1:3, significantly increases the total biofilm biomass comparatively to a $C$. albicans monoculture or ratio of $C$. albicans to $C$. glabrata of 1:1. This co-culture biofilm exhibited a high heterogenicity with C. albicans hyphae and C. glabrata cells clustered together in a 3D-structure. Interestingly, an upregulation of HWP1 and ALS3 genes is observed in this mixed-species biofilm, as well as an increased resistance to caspofungin [3]. C. albicans and C. glabrata are also known to form biofilms with bacteria from different host niches, usually relying on quorum-sensing mechanisms for the establishment of an interaction [20,155]. All the possible interactions between species increase the complexity of this vast field, pointing out the big clinical challenge of biofilm formation.

\section{Host Immune System Evasion}

Throughout infection, when the first line of defense has been breached by invasion into deeper tissues, Candida pathogens have to cope with cells of the host innate immune system. Interaction with the host immune system, and the ability to overcome it, is one of the main virulence features for fungal pathogens.

At early stages of infection, upon an interaction between Candida pathogens and epithelial cells, the former are recognized as invasive microorganisms by Pattern Recognition Receptors (PRRs) localized at host epithelial cell surfaces. PRRs interact with Pathogen Associated Molecular Patterns (PAMPs), such as $\beta$-1,3-glucan or chitin, present on microbial cells, thereby inducing a host response [156,157]. Epithelial cells, that are part of the innate immunity, not only secrete antimicrobial peptides, such as $\beta$-defensins and LL-37 [158-160], to try to control fungal infection, but also release proinflammatory mediators, such as chemokines and cytokines, triggering the recruitment of phagocytic cells, such as neutrophils, macrophages, and dendritic cells. These innate immune system cells also have PRRs in their surfaces, such as the C-type lectin receptor Dectin-1 [161], allowing the recognition of the invading pathogens and thereby inducing phagocytosis [162]. After phagocytosis, dendritic cells are responsible for the link between innate and adaptative antifungal immunity, presenting the Candida-specific antigens to naïve T-helper cells [163]. Therefore, in an immunocompetent host, this host-Candida interaction ultimately leads to the elimination of the pathogen. Otherwise, in immunocompromised individuals, a persistent infection, such as chronic mucocutaneous candidiasis, candidemia and/or persistent visceral candidiasis might be established.

Immune interaction can be translated in distinct spectrums, from avoidance of recognition by host immune cells to escaping or surviving immune attack. Masking PAMPs on the cell wall to avoid recognition, macrophage activation, and consequent phagocytosis is a common strategy of fungal pathogens during interaction with immune cells [164]. Generally, yeasts' cell wall is composed of a carbohydrate-rich inner layer and a protein-rich outer layer of heavily mannosylated proteins and phospholipomannan [165]. The outer layer acts as a shield of immunostimulatory components of the inner layer, such as $\beta-1,3$-glucan or chitin, playing a key role in protection and evasion from immune recognition [166]. $\beta$-1,3-glucan is the main polysaccharide present in the cell wall of C. albicans, C. glabrata, and other pathogenic Candida species, and is a key PAMP recognized by the host immune system [167]. Recognition of $\beta-1,3$-glucan by Dectin-1 receptor prompts phagocytosis by macrophages and neutrophils [161]. 
In order to avoid immune recognition, C. albicans resorts to cell wall remodeling, effectively masking $\beta$-glucan from the cell surface. The first reported case of active PAMP masking by Candida species was reported by Ballou et al. (2016) [167]. C. albicans was shown to mask $\beta$-glucan in response to lactate [167], which is a relevant physiological metabolite present in Candida niches, such as the vaginal tract and blood, or produced by the host microbiota [168], with which Candida interact. Lactate-mediated $\beta$-glucan masking is modulated by a signaling pathway associated with the G-protein coupled receptor Gpr1 and the transcription factor Crz1 [167]. This pathway reduces C. albicans uptake by macrophages and decreases the inflammatory response (TNF $\alpha$ and MIP1 $\alpha$ ) and neutrophil recruitment [167]. The participation of lactate was also observed later in low oxygen environments [169]. C. albicans was found to mask $\beta$-glucan upon oxygen deprivation, hindering recognition by Dectin-1 of polymorphonuclear leukocytes (PMNs). This was seen to modulate PMN responses, crippling phagocytosis, action of extracellular DNA traps, and reactive oxygen species (ROS) production [169]. Interestingly, $\beta$-glucan masking was prolonged by the build-up of lactate levels produced by PMNs [169]. Later, another study reported that hypoxia promotes $\beta$-glucan masking in C. albicans [170]. Hypoxia-induced masking is dependent on mitochondrial function and cAMP-protein kinase A (PKA) signaling, leading to reduced macrophage phagocytosis and cytokine (IL-10, RANTES, and TNF- $\alpha$ ) production [170].

Changes in carbon source result in cell wall modifications with correspondent changes in virulence and immune properties [108,171]. As mentioned before, the cell wall is a complex structure with not only glucan, but also mannans, phosphomannans, and chitin [157], although distinct Candida species display different glucan exposure and mannan complexity [166]. $\beta$-glucans and chitin are located in the inner-most layer, while mannans are present in the outer layer [172-174]. Because of such structure, mannan plays an important role in reducing immunogenic exposure of $\beta$-glucan [175], but coordinated chitin and glucan exposure has also been reported to occur in C. albicans [176-178]. Moreover, cell wall structure and mannans affect virulence in different ways in C. albicans and C. glabrata [179-181]. Recently, mannan structure was found to affect glucan exposure in both C. albicans and C. glabrata, albeit in distinct ways. Deletion of mannosyltransferase family genes was associated with loss of negatively-charged acid-labile mannan and less efficient glucan masking in C. albicans (e.g., $\Delta c g m n n 2)$, while in C. glabrata increased glucan exposure density was associated with mutants displaying shorter backbones (e.g., $\Delta c g m n n 1$ and $\Delta$ cganp1) [166]. Previously, another study had shown that the $\beta-1,6-$ mannosyltransferase encoded by $C$. albicans MNN10 is required for backbone synthesis and influences immune recognition [182]. Absence of Mnn10 results in reduced C. albicans virulence, enhanced antifungal immunity by $\mathrm{T}$ helper cells, and increased recruitment of monocytes and neutrophils. Reinforcing the notion of a complex interplay among cell wall polysaccharydes, mannosyltransferase activity was also associated with $\beta$-1,3-glucan masking from Dectin-1 recognition and modulatory action of cytokine production by macrophages [182]. Another study showed how C. albicans cell wall responds to immune attacks by NETs [176]. $\beta$-glucan exposure and enhanced Dectin-1 recognition is dependent on fungal-pathogen crosstalk, as this response is dependent on neutrophil NET-mediated damage and fungal signaling cascades based on the MAP kinase Hog1. Cell wall structure in response to a neutrophil attack was found to affect more than one component, as Hog1 signaling leads to chitin deposition via the chitin synthase Chs3 and posterior cell wall remodeling via Sur7 and Phr1. Accordingly, with the enhanced immune recognition by Dectin-1 after a NET-mediated attack, macrophage cytokine response was also increased [176].

Much like C. albicans, C. glabrata resorts to cell wall remodeling in order to avoid the host's immune system, although the underlying mechanisms are mostly unknown. As indicated by increased $\mathrm{TNF} \alpha$ secretion and increased efficacy of pathogen killing by macrophages, deletion mutants with disturbed cell wall integrity and altered accessibility of PAMPs caused a stronger inflammatory response. C. glabrata deletion mutants lacking cell surface-associated proteases (yapsins) or mutants with defective protein glycosylation were related with a stronger inflammatory response by macrophages $[13,181]$. Nevertheless, mutations affecting mannan, but not those affecting glucan or chitin, were found to 
reduce the uptake of $C$. glabrata cells by murine macrophages, suggesting that mannose side chains or mannosylated proteins are ligands recognized by macrophages [183].

Knowledge regarding the PRRs responsible for C. glabrata recognition by macrophages is limited. Notwithstanding, as in C. albicans infections, C-type lectin receptors are thought to be involved in C. glabrata recognition by the host immune system. Specifically, dectin-1 and dectin-2, which recognize cell wall $\beta$-glucan, and mannan and $\beta$-glucan respectively, have been reported to be involved in the recognition of this pathogen $[184,185]$.

Unlike C. albicans that put effort in escaping the immune system, it is hypothesized that inducing the recruitment of macrophages to the site of infection in vivo is part of the C. glabrata immune system evasion strategy [21]. C. glabrata infection did not substantially activate any MAPK pathway, including Erk1/2 (Extracellular signal-regulated kinases), SAPK/JNK (Stress-activated protein kinases/Jun amino-terminal kinases), and NF- $\mathrm{kB}$ signaling. Accordingly, it was found that upon infection of macrophages, the only cytokine significantly induced is GM-CSF, whereas the induction of other proinflammatory cytokines (TNF- $\alpha$, IL-1 $\beta$, IL-6, IL-8, and IFN- $\gamma$ ) is low $[21,65,186]$. GM-CSF is a potent activator of macrophages and induces differentiation of precursor cells as well as the recruitment of macrophages to sites of infection. This may explain the enhanced tissue infiltration of mononuclear cells, but not neutrophils, observed in vivo [186]. Considering the ability of C. glabrata to survive and replicate within macrophages, it is therefore speculated that persistence within macrophages is a possible strategy of immune evasion in this pathogen [21].

Immune evasion by pathogens also entails escaping from the complement system, another pathway of the innate immune system that facilitates phagocytosis. To evade immune response, several pathogens were shown to sequester or bind complement regulators, such as factor $\mathrm{H}(\mathrm{FH})$ [187-190]. C. albicans expresses the glucose transporter Hgt1 that binds FH, therefore reducing complement regulatory activity and limiting phagocytosis and killing by neutrophils [191]. SAP proteases produced by C. albicans not only cause tissue damage [192], but also contribute to immune evasion, as Sap2 is able to cleave antimicrobial peptides and complement proteins $[193,194]$. C. albicans Sap2 also cleaves $\mathrm{FH}$ and its receptors (CR3 and CR4) on macrophages, thus limiting their activation [195]. Additionally, C. albicans was also seen to bind yet another complement regulator (vitronectin) to modulate the hosts innate response [196]. The C. albicans $\mathrm{pH}$-regulated protein Pra1 was recently implicated in the modulation of immune response [197,198]. It was seen to cleave the complement component C3, blocking the complement effector function and interfering with killing by neutrophils [197]. Pra1 is also implicated in adaptive immune response, as it binds to mouse $\mathrm{CD} 4^{+} \mathrm{T}$ cells and reduces cytokine (IFN $r$ and TNF) secretion and antigen stimulation [198].

Ultimately, many yeast cells are engulfed by macrophages, hence survival and replication or subsequent escape remain important features. Upon phagocytosis, the phagosome carrying the ingested microorganism, fusion with a lysosome is one central antimicrobial mechanism of macrophages [164]. In the phagolysosome, fungal pathogens have to survive the harsh environment, typically characterized by carbon source limitation, production of reactive oxygen and nitrogen species, and acidification of the phagosomal compartment [199-201]. Mature phagolysosomes are normally strongly acidified, inducing antimicrobial effector mechanisms such as the activity of hydrolytic enzymes. Nonetheless, both C. albicans and C. glabrata are able to actively limit phagosome maturation in macrophages to prevent acidification and limit hydrolytic attack [21,202]. Environmental alkalinization by amino acid use as carbon sources, which results in ammonia extrusion, has been acknowledged as a strategy of these pathogens to actively raise phagosome $\mathrm{pH}[199,203,204]$. Moreover, extracellular $\mathrm{pH}$-raising triggers the yeast-hyphal switch in C. albicans $[199,204]$. Regarding carbon source availability, macrophages actively deprive pathogens of glucose, and therefore alternative carbon sources must support fungal growth. Accordingly, genes coding for enzymes of glyoxylate cycle, gluconeogenesis, and $\beta$-oxidation of fatty acids were found to be upregulated in both C. glabrata and C. albicans cells ingested by macrophages $[13,18,205]$. Very recently, the glyoxylate cycle gene ICL1 was demonstrated to be crucial for the survival of $C$. glabrata in response to macrophage engulfment [206]. Disruption of ICL1 rendered 
C. glabrata cells unable to utilize acetate, ethanol, or oleic acid and conferred a severe attenuation of virulence in the mouse model of invasive candidiasis [206]. Further, genes of the methylcitrate cycle, which is important for the degradation of fatty acid chains and which allows the use of lipids as alternative carbon sources, were also found to be upregulated in C. glabrata [13]. Downregulation of protein synthesis as well as upregulation of amino acid biosynthetic pathways and amino acid and ammonium transport genes are features of the nitrogen deprivation faced by fungal cells inside the macrophages [13].

Although being mainly known by macrophage escape, strategies to counteract oxidative and nitrosative stress have been described in C. albicans. For instance, flavodoxin-like proteins are part of the antioxidant response of this species by reducing ubiquinone, which acts as a membrane antioxidant [207]. Expression of four flavodoxin genes (PST1, PST2, PST3, YCP4) is required for C. albicans virulence and resist neutrophil attack [207]. Other than oxidative burst modulation, C. albicans was also reported to modulate the nitrosative stress exerted by macrophages [208]. Nitric oxide production is dependent on the enzyme nitric oxide synthase, which utilizes arginine as a substrate. By increasing chitin exposure, $C$. albicans induces the host arginase- 1 enzyme, which competes with the nitric oxide synthase enzyme and prevents the conversion of L-arginine to nitric oxide [208]. Interestingly, the use of amino acids as carbon source is much more prominent in C. albicans than other fungi [199] and amino acid metabolism has been associated with more than one mechanism of phagocyte escape/survival. Arginine was also found to play a role in hyphal development upon phagocytosis by macrophages, thus contributing to escaping the phagosome [209]. Additionally, in poor glucose conditions, C. albicans excretes amino acid-derived ammonia that increases external $\mathrm{pH}$ and interferes with the acidification of the phagosome [204,210], as mentioned before. Moreover, the transcription factor Stp2 involved in amino acid acquisition, is required to prevent phagosome acidification [204,209] based on the SPS amino acid sensing system [211]. Regarding the contribution of nitrosative stress to macrophage defense against $C$. glabrata, it is known that this pathogen induces only low NO production by murine macrophages [13].

C. glabrata shows increased tolerance to oxidative stress when compared to other yeasts, including Saccharomyces cerevisiae and C. albicans [212], mostly associated with the activity of the catalase Cta1, the superoxide dismutases Sod1/Sod2 and the glutathione and thioredoxin pathways [212-214]. Despite this, it is speculated that ROS play a minor role in killing C. glabrata cells, since experimental inhibition of ROS production in macrophages did not result in increased fungal survival [215]. In contrast to C. albicans, mobilization of intracellular resources via autophagy is an important virulence factor that supports the viability of $C$. glabrata in the phagosomal compartment of innate immune cells [23]. Phagocytosis induces peroxisome production in C. glabrata cells, which are then degraded via pexophagy, a specialized form of autophagy [23].

Moreover, besides carbon and nitrogen, trace elements such as iron are important for yeast growth. Macrophage-engulfed C. albicans upregulate a set of genes involved in iron homeostasis, for example, the ferric reductase genes FRE3 and FRE7, as well as uptake systems for other trace metals, such as copper (CTR1) and zinc (ZRT2) [18]. C. glabrata is also able to sense and respond to iron limitation, although it has not been shown to use host iron-binding proteins as iron sources and is unable to use heme or hemoglobin. Instead, C. glabrata uses the siderophore-iron transporter Sit1, which is essential for utilization of ferrichrome as an iron source under iron-deficient conditions, and for iron-dependent survival in macrophages [216,217]. This iron acquisition system improves the fitness of C. glabrata when it is subsequently exposed to macrophages [216]. Recently, PI3K-kinase (encoded by VPS34) signaling was revealed to play a central role in C. glabrata iron metabolism and host colonization. However, the strategies by which C. glabrata gains iron within macrophages remain unknown [218].

While $C$. glabrata is most known for a persistence strategy and survival inside macrophages, due to its high-intrinsic stress tolerance, $C$. albicans is best known for active escape via hyphal growth and phagocyte piercing. In 2014, the model of macrophage piercing due to polarized growth of hyphae was challenged by two studies [17,219]. The study by Wellington et al. (2014) [219] showed that C. albicans 
escape is not exclusively due to disruption by hyphae. The pyroptosis pathway, a proinflammatory programmed cell-death process that is dependent on caspase-1, leads to interleukin production and macrophage lysis [220] and occurs concurrently with hyphae-mediated damage. Pyroptosis has been described to occur in response to intracellular bacteria, and thus is hypothesized to achieve the goal of destroying macrophages themselves in order to eradicate phagocyted pathogens [221]. C. albicans yeast-to-hyphae transition induces macrophage pyroptosis, therefore indicating that phagocyte damage caused by this pathogen is a more complex mechanism than originally postulated $[17,219]$. Accordingly, the study by Uwamahoro et al. (2014) [17] added more evidence of this escape mechanism. The triggering of pyroptosis is necessary for full macrophage damage upon hyphal formation and is activated in early phagocytosis, followed by a more robust hyphal formation that is indeed the main mechanism of macrophage killing in a later phase [17].

Candida thrives on multiple carbon sources to survive inside macrophages, but these depend on glucose for viability. Recently, Tucey et al. (2018) [222] demonstrated that C. albicans exploits this limitation by depleting glucose, and triggering rapid macrophage death, in vitro. Additionally, they showed that $C$. albicans infection promotes the disruption of host glucose homeostasis in vivo and verified that glucose supplementation improves host outcomes under systemic fungal infection [222]. Thus, depriving host immune cells for glucose seems to be one mechanism of $C$. albicans to induce phagocyte cell death and actively escape from those. Moreover, it was recently discovered that candidalysin is both a central trigger for Nlrp3 inflammasome-dependent caspase-1 activation via potassium efflux, and a key driver of inflammasome-independent cytolysis of macrophages and dendritic cells upon infection with C. albicans [223]. This study suggests that candidalysin-induced cell damage is a third mechanism by which $C$. albicans induces phagocyte cell death in addition to damage caused by pyroptosis and the growth of glucose-consuming hyphae [223]. C. albicans-induced activation of the Nlrp3 inflammasome, leading to secretion of IL-1 $\beta$ cytokine, is a crucial myeloid cell immune response needed for antifungal host defense [224]. Very recently, Rogiers and co-workers (2019) [225] identified candidalysin as the fungal trigger for Nlrp3 inflammasome-mediated maturation and secretion of IL-1 $\beta$ from primary macrophages. Therefore, the expression of candidalysin is speculated to be one of the molecular mechanisms by which hyphal transformation equips $C$. albicans with its proinflammatory capacity to prompt the release of bioactive IL-1 $\beta$ from macrophages [225].

A more controversial evasion mechanism, based on quorum-sensing stimulation of immune recognition, has been reported in both C. albicans and C. glabrata. In the case of $C$. albicans, white cells specifically (not opaque cells) secrete E,E-Farnesol, a stimulator of macrophage chemokinesis [226]. Farnesol secretion was found to increase macrophage migration and tissue infiltration [226]. This strategy has been associated with immune evasion by the concealing of the pathogens inside immune cells themselves, an environment where Candida species can survive.

Conversely to C. albicans, C. glabrata is incapable of hyphal differentiation, failing at this virulence trait. Although never observed for clinical isolates, interestingly, work by Brunke et al. (2014) [227] has shown that $C$. glabrata cells co-incubated during six months with macrophages, were able to produce pseudohyphae structures and evolve into a hypervirulent phenotype characterized by higher macrophage damage and faster escape.

Overall, the two more prevalent pathogenic yeasts, C. albicans and C. glabrata, follow two main different strategies to achieve the same ultimate goal: survive host immune response. On one hand, C. albicans hyphal forms actively pierce the membrane of macrophages as a mechanism of killing and escape. On the other hand, C. glabrata, that lacks morphological plasticity, survives and replicates within macrophages due to its remarkable ability to surpass its harsh environment, ultimately leading to macrophage lysis after several days due to fungal cells overload [21] (Figure 3). 

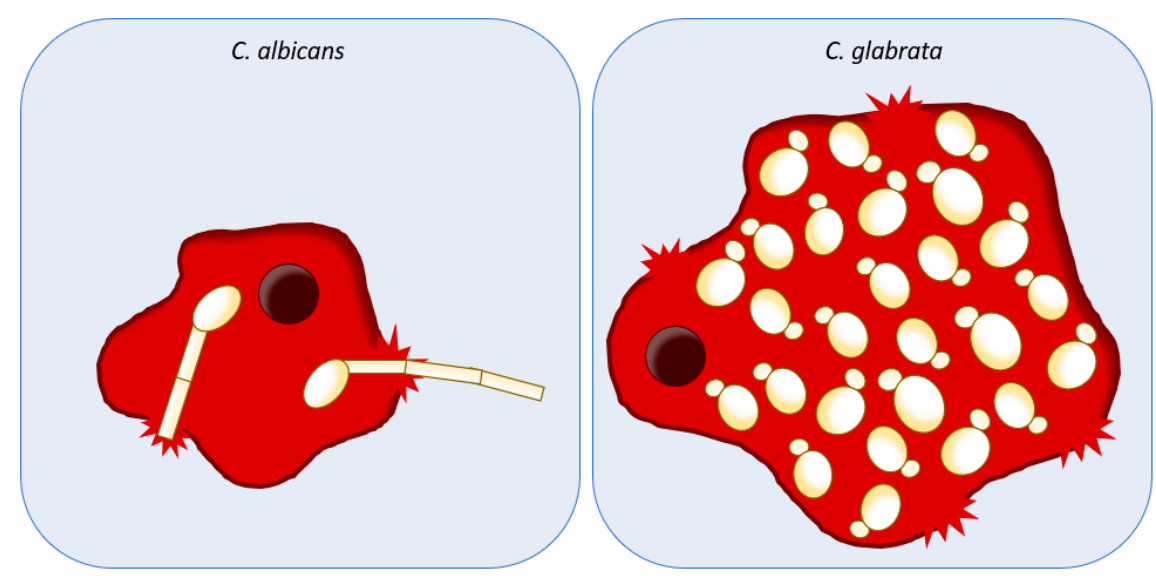

Figure 3. Schematic representation of C. albicans and C. glabrata host immune system evasion. C. albicans actively escape from host immune system cells through hyphal growth and phagocyte piercing. C. glabrata is most known for a persistence strategy, surviving and thriving inside macrophages, ultimately leading to immune cells lysis due to fungal load.

\section{Conclusion and Perspectives}

The pathogenic yeasts C. albicans and C. glabrata are the two most prevalent Candida species isolated from candidiasis patients worldwide, yet they are phylogenetically, genetically, and phenotypically very different. Indeed, each species displays divergent virulence traits, indicating differential adaptation to the human host.

A greater number of virulence mechanisms has been described in C. albicans, most of which are not known to occur in C. glabrata. Yeast-to-hyphae dimorphism is one of the most striking divergent features. Hyphal morphology is associated with several key C. albicans traits (tissue invasion, biofilm formation, immune evasion), but is absent in C. glabrata. The result is that C. glabrata must have acquired other molecular mechanisms to reach the same goals. While tissue invasion in C. albicans occurs by proteolytic enzyme secretion and hyphal penetration of host tissues, C. glabrata-induced tissue damage is quite negligent in comparison and is thought to occur via endocytosis induction by host cells.

A similar observation can be made regarding biofilm formation, where C. albicans expresses hyphal-specific adhesins and regulators required for adhesion, while C. glabrata biofilms are much less "bulky". Morphological dimorphism also supports noticeable differences in immune evasion, as hyphal development and phagosome piercing is the main phagocyte escape mechanism employed by C. albicans, while such a strategy is absent in C. glabrata, which rather survives (and thrives) in the phagosome.

Dissimilar traits between C. albicans and C. glabrata have been identified, and such attributes have been extensively studied in C. albicans. However, the molecular mechanisms specific to C. glabrata that allow such a disparate species to cause human candidiasis demand further scrutiny. Indeed, the up rise of C. glabrata as a key fungal pathogen can only be prevented with specific therapeutic options that match its specific virulence traits.

Author Contributions: M.G., P.P., M.C., D.P., R.V. and M.C.T. contributed to the literature review and manuscript drafting, each author in their specific field of expertise. M.G. wrote the manuscript and prepared the illustrative figures. M.C.T. conceived the manuscript structure, supervised its writing, and reviewed all contents thoroughly.

Funding: Work conducted in this field was supported by "Fundação para a Ciência e a Tecnologia" (FCT) (Contracts PTDC/BBB-BIO/4004/2014 and PTDC/BII-BIO/28216/2017, PhD grants to MG, PP, and MC). Funding received by iBB-Institute for Bioengineering and Biosciences from FCT-Portuguese Foundation for Science and Technology (UID/BIO/04565/2013) and from Programa Operacional Regional de Lisboa 2020 (Project N. 007317) is acknowledged.

Conflicts of Interest: The authors declare no conflict of interest. 


\section{References}

1. Brown, G.D.; Denning, D.W.; Gow, N.A.R.; Levitz, S.M.; Netea, M.G.; White, T.C. Hidden Killers: Human Fungal Infections. Sci. Transl. Med. 2012, 4, 165rv13. [CrossRef] [PubMed]

2. Bassetti, M.; Peghin, M.; Timsit, J.-F. The current treatment landscape: Candidiasis. J. Antimicrob. Chemother. 2016, 71, ii13-ii22. [CrossRef]

3. Olson, M.L.; Jayaraman, A.; Kao, K.C. Relative Abundances of Candida albicans and Candida glabrata in In Vitro Coculture Biofilms Impact Biofilm Structure and Formation. Appl. Environ. Microbiol. 2018, 84, e02769-17. [CrossRef]

4. Cho, I.; Blaser, M.J. The human microbiome: At the interface of health and disease. Nat. Rev. Genet. 2012, 13, 260-270. [CrossRef] [PubMed]

5. Underhill, D.M.; Iliev, I.D. The mycobiota: Interactions between commensal fungi and the host immune system. Nat. Rev. Immunol. 2014, 14, 405-416. [CrossRef]

6. Wisplinghoff, H.; Bischoff, T.; Tallent, S.M.; Seifert, H.; Wenzel, R.P.; Edmond, M.B. Nosocomial Bloodstream Infections in US Hospitals: Analysis of 24,179 Cases from a Prospective Nationwide Surveillance Study. Clin. Infect. Dis. 2004, 39, 309-317. [CrossRef]

7. Jones, T.; Federspiel, N.A.; Chibana, H.; Dungan, J.; Kalman, S.; Magee, B.B.; Newport, G.; Thorstenson, Y.R.; Agabian, N.; Magee, P.T.; et al. The diploid genome sequence of Candida albicans. Proc. Natl. Acad. Sci. USA 2004, 101, 7329-7334. [CrossRef] [PubMed]

8. Hoyer, L.L. The ALS gene family of Candida albicans. Trends Microbiol. 2001, 9, 176-180. [CrossRef]

9. Ghannoum, M.A. Potential role of phospholipases in virulence and fungal pathogenesis. Clin. Microbiol. Rev. 2000, 13, 122-143. [CrossRef] [PubMed]

10. Calderone, R.A.; Fonzi, W.A. Virulence factors of Candida albicans. Trends Microbiol. 2001, 9, 327-335. [CrossRef]

11. Li, L.; Kashleva, H.; Dongari-Bagtzoglou, A. Cytotoxic and cytokine-inducing properties of Candida glabrata in single and mixed oral infection models. Microb. Pathog. 2007, 42, 138-147. [CrossRef] [PubMed]

12. de Groot, P.W.J.; Kraneveld, E.A.; Yin, Q.Y.; Dekker, H.L.; Groß, U.; Crielaard, W.; de Koster, C.G.; Bader, O.; Klis, F.M.; Weig, M. The Cell Wall of the Human Pathogen Candida glabrata: Differential Incorporation of Novel Adhesin-Like Wall Proteins. Eukaryot. Cell 2008, 7, 1951-1964. [CrossRef]

13. Kaur, R.; Ma, B.; Cormack, B.P. A family of glycosylphosphatidylinositol-linked aspartyl proteases is required for virulence of Candida glabrata. Proc. Natl. Acad. Sci. USA 2007, 104, 7628-7633. [CrossRef]

14. Kaur, R.; Domergue, R.; Zupancic, M.L.; Cormack, B.P. A yeast by any other name: Candida glabrata and its interaction with the host. Curr. Opin. Microbiol. 2005, 8, 378-384. [CrossRef] [PubMed]

15. Brunke, S.; Hube, B. Two unlike cousins: Candida albicans and C. glabrata infection strategies. Cell. Microbiol. 2013, 15, 701-708. [CrossRef] [PubMed]

16. Kasper, L.; Seider, K.; Hube, B. Intracellular survival of Candida glabrata in macrophages: Immune evasion and persistence. FEMS Yeast Res. 2015, 15, fov042. [CrossRef] [PubMed]

17. Uwamahoro, N.; Verma-Gaur, J.; Shen, H.H.; Qu, Y.; Lewis, R.; Lu, J.; Bambery, K.; Masters, S.L.; Vince, J.E.; Naderer, T.; et al. The pathogen Candida albicans hijacks pyroptosis for escape from macrophages. MBio 2014, 5, e00003-14. [CrossRef]

18. Lorenz, M.C.; Bender, J.A.; Fink, G.R. Transcriptional response of Candida albicans upon internalization by macrophages. Eukaryot. Cell 2004, 3, 1076-1087. [CrossRef]

19. Mayer, F.L.; Wilson, D.; Hube, B. Candida albicans pathogenicity mechanisms. Virulence 2013, 4, 119-128. [CrossRef]

20. Cavalheiro, M.; Teixeira, M.C. Candida Biofilms: Threats, Challenges, and Promising Strategies. Front. Med. 2018, 5, 28. [CrossRef]

21. Seider, K.; Brunke, S.; Schild, L.; Jablonowski, N.; Wilson, D.; Majer, O.; Barz, D.; Haas, A.; Kuchler, K.; Schaller, M.; et al. The facultative intracellular pathogen Candida glabrata subverts macrophage cytokine production and phagolysosome maturation. J. Immunol. 2011, 187, 3072-3086. [CrossRef]

22. Dementhon, K.; El-Kirat-Chatel, S.; Noël, T. Development of an in vitro model for the Multi-Parametric quantification of the cellular interactions between Candida yeasts and phagocytes. PLoS ONE 2012, 7, e32621. [CrossRef] [PubMed] 
23. Roetzer, A.; Gratz, N.; Kovarik, P.; Schãller, C. Autophagy supports Candida glabrata survival during phagocytosis. Cell. Microbiol. 2010, 12, 199-216. [CrossRef] [PubMed]

24. Yan, L.; Yang, C.; Tang, J. Disruption of the intestinal mucosal barrier in Candida albicans infections. Microbiol. Res. 2013, 168, 389-395. [CrossRef]

25. Allert, S.; Förster, T.M.; Svensson, C.-M.; Richardson, J.P.; Pawlik, T.; Hebecker, B.; Rudolphi, S.; Juraschitz, M.; Schaller, M.; Blagojevic, M.; et al. Candida albicans-Induced Epithelial Damage Mediates Translocation through Intestinal Barriers. MBio 2018, 9, e00915-18. [CrossRef]

26. Cassone, A. Vulvovaginal Candida albicans infections: Pathogenesis, immunity and vaccine prospects. BJOG Int. J. Obstet. Gynaecol. 2015, 122, 785-794. [CrossRef]

27. Bokor-Bratic, M.; Cankovic, M.; Dragnic, N. Unstimulated whole salivary flow rate and anxiolytics intake are independently associated with oral Candida infection in patients with oral lichen planus. Eur. J. Oral Sci. 2013, 121, 427-433. [CrossRef]

28. Hibino, K.; Samaranayake, L.P.; Hägg, U.; Wong, R.W.K.; Lee, W. The role of salivary factors in persistent oral carriage of Candida in humans. Arch. Oral Biol. 2009, 54, 678-683. [CrossRef]

29. Goyer, M.; Loiselet, A.; Bon, F.; L'Ollivier, C.; Laue, M.; Holland, G.; Bonnin, A.; Dalle, F. Intestinal Cell Tight Junctions Limit Invasion of Candida albicans through Active Penetration and Endocytosis in the Early Stages of the Interaction of the Fungus with the Intestinal Barrier. PLoS ONE 2016, 11, e0149159. [CrossRef]

30. Dalle, F.; Wãchtler, B.; L'Ollivier, C.; Holland, G.; Bannert, N.; Wilson, D.; Labruãre, C.; Bonnin, A.; Hube, B. Cellular interactions of Candida albicans with human oral epithelial cells and enterocytes. Cell. Microbiol. 2010, 12, 248-271. [CrossRef]

31. Phan, Q.T.; Myers, C.L.; Fu, Y.; Sheppard, D.C.; Yeaman, M.R.; Welch, W.H.; Ibrahim, A.S.; Edwards, J.E.; Filler, S.G. Als3 Is a Candida albicans Invasin That Binds to Cadherins and Induces Endocytosis by Host Cells. PLoS Biol. 2007, 5, e64. [CrossRef]

32. Sun, J.N.; Solis, N.V.; Phan, Q.T.; Bajwa, J.S.; Kashleva, H.; Thompson, A.; Liu, Y.; Dongari-Bagtzoglou, A.; Edgerton, M.; Filler, S.G. Host Cell Invasion and Virulence Mediated by Candida albicans Ssa1. PLoS Pathog. 2010, 6, e1001181. [CrossRef]

33. Zakikhany, K.; Naglik, J.R.; Schmidt-Westhausen, A.; Holland, G.; Schaller, M.; Hube, B. In vivo transcript profiling of Candida albicans identifies a gene essential for interepithelial dissemination. Cell. Microbiol. 2007, 9, 2938-2954. [CrossRef] [PubMed]

34. Park, H.; Myers, C.L.; Sheppard, D.C.; Phan, Q.T.; Sanchez, A.A.; Edwards, J.E.; Filler, S.G. Role of the fungal Ras-protein kinase A pathway in governing epithelial cell interactions during oropharyngeal candidiasis. Cell. Microbiol. 2004, 7, 499-510. [CrossRef] [PubMed]

35. Li, Z.; Nielsen, K. Morphology Changes in Human Fungal Pathogens upon Interaction with the Host. J. Fungi 2017, 3, 66. [CrossRef] [PubMed]

36. Jacobsen, I.D.; Wilson, D.; Wächtler, B.; Brunke, S.; Naglik, J.R.; Hube, B. Candida albicans dimorphism as a therapeutic target. Expert Rev. Anti-Infect. Ther. 2012, 10, 85-93. [CrossRef]

37. Feng, Q.; Summers, E.; Guo, B.; Fink, G. Ras signaling is required for serum-induced hyphal differentiation in Candida albicans. J. Bacteriol. 1999, 181, 6339-6346.

38. Maidan, M.M.; De Rop, L.; Serneels, J.; Exler, S.; Rupp, S.; Tournu, H.; Thevelein, J.M.; Van Dijck, P. The G Protein-coupled Receptor Gpr1 and the G $\alpha$ Protein Gpa2 Act through the cAMP-Protein Kinase A Pathway to Induce Morphogenesis in Candida albicans. Mol. Biol. Cell 2005, 16, 1971-1986. [CrossRef]

39. Biswas, K.; Morschhäuser, J. The Mep2p ammonium permease controls nitrogen starvation-induced filamentous growth in Candida albicans. Mol. Microbiol. 2005, 56, 649-669. [CrossRef]

40. Stoldt, V.R.; Sonneborn, A.; Leuker, C.E.; Ernst, J.F. Efg1p, an essential regulator of morphogenesis of the human pathogen Candida albicans, is a member of a conserved class of bHLH proteins regulating morphogenetic processes in fungi. EMBO J. 1997, 16, 1982-1991. [CrossRef]

41. Zeidler, U.; Lettner, T.; Lassnig, C.; Müller, M.; Lajko, R.; Hintner, H.; Breitenbach, M.; Bito, A. UME6 is a crucial downstream target of other transcriptional regulators of true hyphal development in Candida albicans. FEMS Yeast Res. 2009, 9, 126-142. [CrossRef]

42. Murad, A.M.A.; Leng, P.; Straffon, M.; Wishart, J.; Macaskill, S.; MacCallum, D.; Schnell, N.; Talibi, D.; Marechal, D.; Tekaia, F; et al. NRG1 represses yeast-hypha morphogenesis and hypha-specific gene expression in Candida albicans. EMBO J. 2001, 20, 4742-4752. [CrossRef] 
43. Braun, B.R.; Kadosh, D.; Johnson, A.D. NRG1, a repressor of filamentous growth in C.albicans, is down-regulated during filament induction. EMBO J. 2001, 20, 4753-4761. [CrossRef] [PubMed]

44. Watts, H.J.; Veacutery, A.-A.; Perera, T.H.S.; Davies, J.M.; Gow, N.A.R. Thigmotropism and stretch-activated channels in the pathogenic fungus Candida albicans. Microbiology 1998, 144, 689-695. [CrossRef] [PubMed]

45. Tscherner, M.; Giessen, T.W.; Markey, L.; Kumamoto, C.A.; Silver, P.A. A Synthetic System That Senses Candida albicans and Inhibits Virulence Factors. ACS Synth. Biol. 2019, 8, 434-444. [CrossRef]

46. Chen, H.; Fujita, M.; Feng, Q.; Clardy, J.; Fink, G.R. Tyrosol is a quorum-sensing molecule in Candida albicans. Proc. Natl. Acad. Sci. USA 2004, 101, 5048-5052. [CrossRef] [PubMed]

47. Naglik, J.R.; Rodgers, C.A.; Shirlaw, P.J.; Dobbie, J.L.; Fernandes-Naglik, L.L.; Greenspan, D.; Agabian, N.; Challacombe, S.J. Differential Expression of Candida albicans Secreted Aspartyl Proteinase and Phospholipase B Genes in Humans Correlates with Active Oral and Vaginal Infections. J. Infect. Dis. 2003, 188, 469-479. [CrossRef] [PubMed]

48. Hube, B.; Naglik, J. Candida albicans proteinases: Resolving the mystery of a gene family. Microbiology 2001, 147, 1997-2005. [CrossRef] [PubMed]

49. Borg-von Zepelin, M.; Beggah, S.; Boggian, K.; Sanglard, D.; Monod, M. The expression of the secreted aspartyl proteinases Sap4 to Sap6 from Candida albicans in murine macrophages. Mol. Microbiol. 1998, 28, 543-554. [CrossRef]

50. Bizzarri, M.; Fuso, A.; Dinicola, S.; Cucina, A.; Bevilacqua, A. Pharmacodynamics and pharmacokinetics of inositol(s) in health and disease. Expert Opin. Drug Metab. Toxicol. 2016, 12, 1181-1196. [CrossRef]

51. Tsang, P.W.-K.; Fong, W.-P.; Samaranayake, L.P. Candida albicans orf19.3727 encodes phytase activity and is essential for human tissue damage. PLoS ONE 2017, 12, e0189219. [CrossRef] [PubMed]

52. Lionakis, M.S.; Lim, J.K.; Lee, C.-C.R.; Murphy, P.M. Organ-Specific Innate Immune Responses in a Mouse Model of Invasive Candidiasis. J. Innate Immunity 2011, 3, 180-199. [CrossRef]

53. Saville, S.P.; Lazzell, A.L.; Monteagudo, C.; Lopez-Ribot, J.L. Engineered control of cell morphology in vivo reveals distinct roles for yeast and filamentous forms of Candida albicans during infection. Eukaryot. Cell 2003, 2, 1053-1060. [CrossRef] [PubMed]

54. Csank, C.; Haynes, K. Candida glabrata displays pseudohyphal growth. FEMS Microbiol. Lett. 2000, 189, 115-120. [CrossRef]

55. Sasani, E.; Khodavaisy, S.; Agha Kuchak Afshari, S.; Darabian, S.; Aala, F.; Rezaie, S. Pseudohyphae formation in Candida glabrata due to $\mathrm{CO}_{2}$ exposure. Curr. Med. Mycol. 2016, 2, 49-52. [CrossRef] [PubMed]

56. Perlroth, J.; Choi, B.; Spellberg, B. Nosocomial fungal infections: Epidemiology, diagnosis, and treatment. Med. Mycol. 2007, 45, 321-346. [CrossRef] [PubMed]

57. Atanasova, R.; Angoulvant, A.; Tefit, M.; Gay, F.; Guitard, J.; Mazier, D.; Fairhead, C.; Hennequin, C. A mouse model for Candida glabrata hematogenous disseminated infection starting from the gut: Evaluation of strains with different adhesion properties. PLoS ONE 2013, 8, e69664. [CrossRef]

58. Jacobsen, I.D.; Große, K.; Berndt, A.; Hube, B. Pathogenesis of Candida albicans infections in the alternative chorio-allantoic membrane chicken embryo model resembles systemic murine infections. PLoS ONE 2011, 6, e19741. [CrossRef]

59. Silva, S.; Henriques, M.C.; Hayes, A.; Oliveira, R.; Azeredo, J.; Williams, D.W. Candida glabrata and Candida albicans co-infection of an in vitro oral epithelium. J. Oral Pathol. Med. 2011, 40, 421-427. [CrossRef]

60. Coco, B.J.; Bagg, J.; Cross, L.J.; Jose, A.; Cross, J.; Ramage, G. Mixed Candida albicans and Candida glabrata populations associated with the pathogenesis of denture stomatitis. Oral Microbiol. Immunol. 2008, 23, 377-383. [CrossRef]

61. Okada, K.; Nakazawa, S.; Yokoyama, A.; Kashiwazaki, H.; Kobayashi, K.; Yamazaki, Y. A Clinical Study of Candida albicans and Candida glabrata Co-infection of Oral Candidiasis. Ronen Shika Igaku 2016, 31, 346-353.

62. Tsay, S.; Williams, S.R.; Benedict, K.; Beldavs, Z.; Farley, M.; Harrison, L.; Schaffner, W.; Dumyati, G.; Blackstock, A.; Guh, A.; et al. A Tale of Two Healthcare-associated Infections: Clostridium difficile Coinfection Among Patients With Candidemia. Clin. Infect. Dis. 2018, 64, 676-679. [CrossRef]

63. Tati, S.; Davidow, P.; McCall, A.; Hwang-Wong, E.; Rojas, I.G.; Cormack, B.; Edgerton, M. Candida glabrata Binding to Candida albicans Hyphae Enables Its Development in Oropharyngeal Candidiasis. PLoS Pathog. 2016, 12, e1005522. [CrossRef] 
64. Alves, C.T.; Wei, X.Q.; Silva, S.; Azeredo, J.; Henriques, M.; Williams, D.W. Candida albicans promotes invasion and colonisation of Candida glabrata in a reconstituted human vaginal epithelium. J. Infect. 2014, 69, 396-407. [CrossRef] [PubMed]

65. Li, L.; Dongari-Bagtzoglou, A. Epithelial GM-CSF induction by Candida glabrata. J. Dent. Res. 2009, 88, 746-751. [CrossRef] [PubMed]

66. Fidel, P.L.; Vazquez, J.A.; Sobel, J.D. Candida glabrata: Review of epidemiology, pathogenesis, and clinical disease with comparison to C. albicans. Clin. Microbiol. Rev. 1999, 12, 80-96. [CrossRef]

67. Fatahinia, M.; Halvaeezadeh, M.; Rezaei-Matehkolaei, A. Comparison of enzymatic activities in different Candida species isolated from women with vulvovaginitis. J. Mycol. Med. 2017, 27, 188-194. [CrossRef]

68. Bassyouni, R.H.; Wegdan, A.A.; Abdelmoneim, A.; Said, W.; Aboelnaga, F. Phospholipase and aspartyl proteinase activities of candida species causing vulvovaginal candidiasis in patients with type 2 diabetes mellitus. J. Microbiol. Biotechnol. 2015, 25, 1734-1741. [CrossRef]

69. De Riceto, É.B.M.; de Menezes, R.P.; Penatti, M.P.A.; dos Pedroso, R.S. Enzymatic and hemolytic activity in different Candida species. Rev. Iberoam. Micol. 2015, 32, 79-82. [CrossRef] [PubMed]

70. Atalay, M.A.; Koc, A.N.; Demir, G.; Sav, H. Investigation of possible virulence factors in Candida strains isolated from blood cultures. Niger. J. Clin. Pract. 2015, 18, 52-55. [PubMed]

71. Pandey, N.; Gupta, M.K.; Tilak, R. Extracellular hydrolytic enzyme activities of the different Candida spp. isolated from the blood of the Intensive Care Unit-admitted patients. J. Lab. Phys. 2018, 10, 392-396.

72. Canela, H.M.S.; Cardoso, B.; Vitali, L.H.; Coelho, H.C.; Martinez, R.; da Ferreira, M.E.S. Prevalence, virulence factors and antifungal susceptibility of Candida spp. isolated from bloodstream infections in a tertiary care hospital in Brazil. Mycoses 2018, 61, 11-21. [CrossRef]

73. Rossoni, R.D.; Barbosa, J.O.; Vilela, S.F.G.; Dos Santos, J.D.; Jorge, A.O.C.; Junqueira, J.C. Correlation of phospholipase and proteinase production of Candida with in vivo pathogenicity in Galleria mellonella. Braz. J. Oral Sci. 2013, 12, 199-204. [CrossRef]

74. Naglik, J.R.; Challacombe, S.J.; Hube, B. Candida albicans Secreted Aspartyl Proteinases in Virulence and Pathogenesis. Microbiol. Mol. Biol. Rev. 2003, 67, 400-428. [CrossRef]

75. Parra-Ortega, B.; Cruz-Torres, H.; Villa-Tanaca, L.; Hernández-Rodríguez, C. Phylogeny and evolution of the aspartyl protease family from clinically relevant Candida species. Mem. Inst. Oswaldo Cruz 2009, 104, 505-512. [CrossRef] [PubMed]

76. Rodrigues, C.F.; Silva, S.; Henriques, M. Candida glabrata: A review of its features and resistance. Eur. J. Clin. Microbiol. Infect. Dis. 2014, 33, 673-688. [CrossRef] [PubMed]

77. Sharma, Y.; Chumber, S.; Kaur, M. Studying the prevalence, species distribution, and detection of in vitro production of phospholipase from Candida isolated from cases of invasive Candidiasis. J. Glob. Infect. Dis. 2017, 9, 8. [CrossRef] [PubMed]

78. Rodrigues, C.; Rodrigues, M.; Silva, S.; Henriques, M. Candida glabrata Biofilms: How Far Have We Come? J. Fungi 2017, 3, 11. [CrossRef]

79. Kumar, K.; Askari, F.; Sahu, M.; Kaur, R. Candida glabrata: A Lot More Than Meets the Eye. Microorganisms 2019, 7, 39. [CrossRef]

80. Hasan, F.; Xess, I.; Wang, X.; Jain, N.; Fries, B.C. Biofilm formation in clinical Candida isolates and its association with virulence. Microbes Infect. 2009, 11, 753-761. [CrossRef]

81. Finkel, J.S.; Mitchell, A.P. Genetic control of Candida albicans biofilm development. Nat. Rev. Microbiol. 2011, 9, 109-118. [CrossRef] [PubMed]

82. Verstrepen, K.J.; Klis, F.M. Flocculation, adhesion and biofilm formation in yeasts. Mol. Microbiol. 2006, 60, 5-15. [CrossRef] [PubMed]

83. Richardson, J.P.; Ho, J.; Naglik, J.R. Candida-Epithelial Interactions. J. Fungi 2018, 4, 22. [CrossRef] [PubMed]

84. Douglas, L.J. Adhesion of Candida species to epithelial surfaces. Crit. Rev. Microbiol. 1987, 15, $27-43$. [CrossRef]

85. Höfs, S.; Mogavero, S.; Hube, B. Interaction of Candida albicans with host cells: Virulence factors, host defense, escape strategies, and the microbiota. J. Microbiol. 2016, 54, 149-169. [CrossRef]

86. de Groot, P.W.J.; Bader, O.; de Boer, A.D.; Weig, M.; Chauhan, N. Adhesins in human fungal pathogens: Glue with plenty of stick. Eukaryot. Cell 2013, 12, 470-481. [CrossRef] 
87. López-Fuentes, E.; Gutiérrez-Escobedo, G.; Timmermans, B.; Van Dijck, P.; De Las Peñas, A.; Castaño, I. Candida glabrata's Genome Plasticity Confers a Unique Pattern of Expressed Cell Wall Proteins. J. Fungi 2018, 4, 67. [CrossRef] [PubMed]

88. Luo, G.; Samaranayake, L.P. Candida glabrata, an emerging fungal pathogen, exhibits superior relative cell surface hydrophobicity and adhesion to denture acrylic surfaces compared with Candida albicans. APMIS 2002, 110, 601-610. [CrossRef] [PubMed]

89. Blanco, M.T.; Sacristán, B.; Lucio, L.; Blanco, J.; Pérez-Giraldo, C.; Gómez-García, A.C. Cell surface hydrophobicity as an indicator of other virulence factors in Candida albicans. Rev. Iberoam. Micol. 2010, 27, 195-199. [CrossRef] [PubMed]

90. Hazen, K.C.; Plotkin, B.J.; Klimas, D.M. Influence of growth conditions on cell surface hydrophobicity of Candida albicans and Candida glabrata. Infect. Immunity 1986, 54, 269-271.

91. Hoyer, L.L.; Green, C.B.; Oh, S.-H.; Zhao, X. Discovering the secrets of the Candida albicans agglutinin-like sequence (ALS) gene family-A sticky pursuit. Med. Mycol. 2008, 46, 1-15. [CrossRef]

92. Cormack, B.; Zordan, R. Adhesins in Opportunistic Fungal Pathogens. In Candida and Candidiasis, 2nd ed.; American Society of Microbiology: Washington, DC, USA, 2012; pp. 243-259.

93. Wächtler, B.; Wilson, D.; Haedicke, K.; Dalle, F.; Hube, B. From attachment to damage: Defined genes of Candida albicans mediate adhesion, invasion and damage during interaction with oral epithelial cells. PLoS ONE 2011, 6, e17046. [CrossRef]

94. Nobile, C.J.; Schneider, H.A.; Nett, J.E.; Sheppard, D.C.; Filler, S.G.; Andes, D.R.; Mitchell, A.P. Complementary adhesin function in C. albicans biofilm formation. Curr. Biol. 2008, 18, 1017-1024. [CrossRef]

95. Younes, S.; Bahnan, W.; Dimassi, H.I.; Khalaf, R.A. The Candida albicans Hwp2 is necessary for proper adhesion, biofilm formation and oxidative stress tolerance. Microbiol. Res. 2011, 166, 430-436. [CrossRef] [PubMed]

96. Li, F.; Svarovsky, M.J.; Karlsson, A.J.; Wagner, J.P.; Marchillo, K.; Oshel, P.; Andes, D.; Palecek, S.P. Eap1p, an adhesin that mediates Candida albicans biofilm formation in vitro and in vivo. Eukaryot. Cell 2007, 6, 931-939. [CrossRef] [PubMed]

97. Li, F.; Palecek, S.P. EAP1, a Candida albicans gene involved in binding human epithelial cells. Eukaryot. Cell 2003, 2, 1266-1273. [CrossRef] [PubMed]

98. Semlali, A.; Killer, K.; Alanazi, H.; Chmielewski, W.; Rouabhia, M. Cigarette smoke condensate increases C. albicans adhesion, growth, biofilm formation, and EAP1, HWP1 and SAP2 gene expression. BMC Microbiol. 2014, 14, 61. [CrossRef] [PubMed]

99. Cormack, B.P.; Ghori, N.; Falkow, S. An adhesin of the yeast pathogen Candida glabrata mediating adherence to human epithelial cells. Science 1999, 285, 578-582. [CrossRef]

100. Halliwell, S.C.; Smith, M.C.A.; Muston, P.; Holland, S.L.; Avery, S.V. Heterogeneous expression of the virulence-related adhesin epa1 between individual cells and strains of the pathogen Candida glabrata. Eukaryot. Cell 2012, 11, 141-150. [CrossRef]

101. De Las Peñas, A.; Pan, S.J.; Castaño, I.; Alder, J.; Cregg, R.; Cormack, B.P. Virulence-related surface glycoproteins in the yeast pathogen Candida glabrata are encoded in subtelomeric clusters and subject to RAP1- and SIR-dependent transcriptional silencing. Genes Dev. 2003, 17, 2245-2258. [CrossRef]

102. Domergue, R.; Castaño, I.; De Las Peñas, A.; Zupancic, M.; Lockatell, V.; Hebel, J.R.; Johnson, D.; Cormack, B.P. Nicotinic acid limitation regulates silencing of Candida adhesins during UTI. Science 2005, 308, 866-870. [CrossRef] [PubMed]

103. Riera, M.; Mogensen, E.; d'Enfert, C.; Janbon, G. New regulators of biofilm development in Candida glabrata. Res. Microbiol. 2012, 163, 297-307. [CrossRef] [PubMed]

104. Iraqui, I.; Garcia-Sanchez, S.; Aubert, S.; Dromer, F.; Ghigo, J.M.; D’Enfert, C.; Janbon, G. The Yak1p kinase controls expression of adhesins and biofilm formation in Candida glabrata in a Sir4p-dependent pathway. Mol. Microbiol. 2005, 55, 1259-1271. [CrossRef]

105. Kraneveld, E.A.; de Soet, J.J.; Deng, D.M.; Dekker, H.L.; de Koster, C.G.; Klis, F.M.; Crielaard, W.; de Groot, P.W.J. Identification and Differential Gene Expression of Adhesin-Like Wall Proteins in Candida glabrata Biofilms. Mycopathologia 2011, 172, 415-427. [CrossRef] 
106. Gómez-Molero, E.; de Boer, A.D.; Dekker, H.L.; Moreno-Martínez, A.; Kraneveld, E.A.; Chauhan, N.; Weig, M.; de Soet, J.J.; de Koster, C.G.; et al. Proteomic analysis of hyperadhesive Candida glabrata clinical isolates reveals a core wall proteome and differential incorporation of adhesins. FEMS Yeast Res. 2015, 15, fov098. [CrossRef]

107. Leiva-Peláez, O.; Gutiérrez-Escobedo, G.; López-Fuentes, E.; Cruz-Mora, J.; De Las Peñas, A.; Castaño, I. Molecular characterization of the silencing complex SIR in Candida glabrata hyperadherent clinical isolates. Fungal Genet. Biol. 2018, 118, 21-31. [CrossRef]

108. Ene, I.V.; Adya, A.K.; Wehmeier, S.; Brand, A.C.; MacCallum, D.M.; Gow, N.A.R.; Brown, A.J.P. Host carbon sources modulate cell wall architecture, drug resistance and virulence in a fungal pathogen. Cell. Microbiol. 2012, 14, 1319-1335. [CrossRef]

109. Van Ende, M.; Wijnants, S.; Van Dijck, P. Sugar Sensing and Signaling in Candida albicans and Candida glabrata. Front. Microbiol. 2019, 10, 99. [CrossRef]

110. Vale-Silva, L.; Beaudoing, E.; Tran, V.D.T.; Sanglard, D. Comparative Genomics of Two Sequential Candida glabrata Clinical Isolates. G3 Genes Genomes Genet. 2017, 7, 2413-2426. [CrossRef] [PubMed]

111. Ni, Q.; Wang, C.; Tian, Y.; Dong, D.; Jiang, C.; Mao, E.; Peng, Y. CgPDR1 gain-of-function mutations lead to azole-resistance and increased adhesion in clinical Candida glabrata strains. Mycoses 2018, 61, 430-440. [CrossRef] [PubMed]

112. Vale-Silva, L.A.; Moeckli, B.; Torelli, R.; Posteraro, B.; Sanguinetti, M.; Sanglard, D. Upregulation of the Adhesin Gene EPA1 Mediated by PDR1 in Candida glabrata Leads to Enhanced Host Colonization. mSphere 2016, 1, e00065-15. [CrossRef]

113. Filler, S.G. Candida-host cell receptor-ligand interactions. Curr. Opin. Microbiol. 2006, 9, 333-339. [CrossRef]

114. Salazar, S.B.; Wang, C.; Münsterkötter, M.; Okamoto, M.; Takahashi-Nakaguchi, A.; Chibana, H.; Lopes, M.M.; Güldener, U.; Butler, G.; Mira, N.P. Comparative genomic and transcriptomic analyses unveil novel features of azole resistance and adaptation to the human host in Candida glabrata. FEMS Yeast Res. 2018, 18, fox079. [CrossRef]

115. Vale-Silva, L.; Ischer, F.; Leibundgut-Landmann, S.; Sanglard, D. Gain-of-function mutations in PDR1, a regulator of antifungal drug resistance in Candida glabrata, control adherence to host cells. Infect. Immunity 2013, 81, 1709-1720. [CrossRef] [PubMed]

116. Nakamura-Vasconcelos, S.S.; Fiorini, A.; Zanni, P.D.; Bonfim-Mendonça, P.; Godoy, J.R.; Almeida-Apolonio, A.A.; Consolaro, M.E.L.; Svidzinski, T.I.E. Emergence of Candida glabrata in vulvovaginal candidiasis should be attributed to selective pressure or virulence ability? Arch. Gynecol. Obstet. 2017, 296, 519-526. [CrossRef]

117. Fox, E.P.; Bui, C.K.; Nett, J.E.; Hartooni, N.; Mui, M.C.; Andes, D.R.; Nobile, C.J.; Johnson, A.D. An expanded regulatory network temporally controls Candida albicans biofilm formation. Mol. Microbiol. 2015, 96, 1226-1239. [CrossRef]

118. Nobile, C.J.; Fox, E.P.; Nett, J.E.; Sorrells, T.R.; Mitrovich, Q.M.; Hernday, A.D.; Tuch, B.B.; Andes, D.R.; Johnson, A.D. A Recently Evolved Transcriptional Network Controls Biofilm Development in Candida albicans. Cell 2012, 148, 126-138. [CrossRef]

119. Nobile, C.J.; Andes, D.R.; Nett, J.E.; Smith, F.J.; Yue, F.; Phan, Q.; Edwards, J.E.; Filler, S.G.; Mitchell, A.P. Critical Role of Bcr1-Dependent Adhesins in C. albicans Biofilm Formation In Vitro and In Vivo. PLoS Pathog. 2006, 2, 0636-0649. [CrossRef] [PubMed]

120. Nobile, C.J.; Nett, J.E.; Andes, D.R.; Mitchell, A.P. Function of Candida albicans adhesin Hwp1 in biofilm formation. Eukaryot. Cell 2006, 5, 1604-1610. [CrossRef]

121. Finkel, J.S.; Xu, W.; Huang, D.; Hill, E.M.; Desai, J.V.; Woolford, C.A.; Nett, J.E.; Taff, H.; Norice, C.T.; Andes, D.R.; et al. Portrait of Candida albicans adherence regulators. PLoS Pathog. 2012, 8, 1-14. [CrossRef]

122. Silva-Dias, A.; Miranda, I.M.; Branco, J.; Monteiro-Soares, M.; Pina-Vaz, C.; Rodrigues, A.G. Adhesion, biofilm formation, cell surface hydrophobicity, and antifungal planktonic susceptibility: Relationship among Candida spp. Front. Microbiol. 2015, 6, 205. [CrossRef]

123. Bendel, C.M. Colonization and epithelial adhesion in the pathogenesis of neonatal candidiasis. Semin. Perinatol. 2003, 27, 357-364. [CrossRef]

124. Lo, H.J.; Köhler, J.R.; DiDomenico, B.; Loebenberg, D.; Cacciapuoti, A.; Fink, G.R. Nonfilamentous C. albicans mutants are avirulent. Cell 1997, 90, 939-949. [CrossRef] 
125. Nobile, C.J.; Mitchell, A.P. Genetics and genomics of Candida albicans biofilm formation. Cell. Microbiol. 2006, 8, 1382-1391. [CrossRef]

126. Douglas, L.J. Candida biofilms and their role in infection. Trends Microbiol. 2003, 11, 30-36. [CrossRef]

127. Ramage, G.; Martínez, J.P.; López-Ribot, J.L. Candida biofilms on implanted biomaterials: A clinically significant problem. FEMS Yeast Res. 2006, 6, 979-986. [CrossRef]

128. Rodríguez-cerdeira, C.; Gregorio, M.C.; Molares-vila, A.; López-barcenas, A.; Fabbrocini, G.; Bardhi, B.; Sinani, A.; Sánchez-blanco, E.; Arenas-guzmán, R.; Hernandez-castro, R. Biofilms and vulvovaginal candidiasis. Colloids Surf. B Biointerfaces 2019, 174, 110-125. [CrossRef] [PubMed]

129. Chandra, J.; Mukherjee, P.K. Candida Biofilms: Development, Architecture, and Resistance. Microbiol. Spectr. 2015, 3. [CrossRef] [PubMed]

130. Kucharíková, S.; Neirinck, B.; Sharma, N.; Vleugels, J.; Lagrou, K.; Van Dijck, P. In vivo Candida glabrata biofilm development on foreign bodies in a rat subcutaneous model. J. Antimicrob. Chemother. 2015, 70, 846-856. [CrossRef]

131. Silva, S.; Henriques, M.; Martins, A.; Oliveira, R.; Williams, D.; Azeredo, J. Biofilms of non-Candida albicans Candida species: Quantification, structure and matrix composition. Med. Mycol. 2009, 47, 681-689. [CrossRef] [PubMed]

132. Seneviratne, C.J.; Silva, W.J.; Jin, L.J.; Samaranayake, Y.H.; Samaranayake, L.P. Architectural analysis, viability assessment and growth kinetics of Candida albicans and Candida glabrata biofilms. Arch. Oral Biol. 2009, 54, 1052-1060. [CrossRef]

133. Ramage, G.; VandeWalle, K.; Wickes, B.L.; López-Ribot, J.L. Characteristics of biofilm formation by Candida albicans. Rev. Iberoam. Micol. 2001, 18, 163-170.

134. Hawser, S.P.; Douglas, L.J. Biofilm formation by Candida species on the surface of catheter materials in vitro. Infect. Immunity 1994, 62, 915-921.

135. Lewis, R.E.; Lo, H.; Raad, I.I.; Kontoyiannis, D.P. Lack of Catheter Infection by the efg1/efg1 cph1/cph1 Double-Null Mutant, a Candida albicans Strain That Is Defective in Filamentous Growth. Antimicrob. Agents Chemother. 2002, 46, 1153-1155. [CrossRef] [PubMed]

136. Ramage, G.; Vandewalle, K.; López-Ribot, J.L.; Wickes, B.L. The filamentation pathway controlled by the Efg1 regulator protein is required for normal biofilm formation and development in Candida albicans. FEMS Microbiol. Lett. 2002, 214, 95-100. [CrossRef] [PubMed]

137. Thein, Z.M.; Samaranayake, Y.H.; Samaranayake, L.P. In vitro biofilm formation of Candida albicans and non-albicans Candida species under dynamic and anaerobic conditions. Arch. Oral Biol. 2007, 52, 761-767. [CrossRef]

138. Fonseca, E.; Silva, S.; Rodrigues, C.F.; Alves, C.T.; Azeredo, J.; Henriques, M. Effects of fluconazole on Candida glabrata biofilms and its relationship with ABC transporter gene expression. Biofouling 2014, 30, 447-457. [CrossRef] [PubMed]

139. Zarnowski, R.; Westler, W.M.; de Lacmbouh, G.A.; Marita, J.M.; Bothe, J.R.; Bernhardt, J.; Lounes-Hadj Sahraoui, A.; Fontaine, J.; Sanchez, H.; Hatfield, R.D.; et al. Novel entries in a fungal biofilm matrix encyclopedia. MBio 2014, 5, e01333-14. [CrossRef] [PubMed]

140. Al-Fattani, M.A.; Douglas, L.J. Biofilm matrix of Candida albicans and Candida tropicalis: Chemical composition and role in drug resistance. J. Med. Microbiol. 2006, 55, 999-1008. [CrossRef]

141. Susewind, S.; Lang, R.; Hahnel, S. Biofilm formation and Candida albicans morphology on the surface of denture base materials. Mycoses 2015, 58, 719-727. [CrossRef]

142. Chandra, J.; Patel, J.P.; Li, J.; Zhou, G.; Mukherjee, P.K.; Mccormick, T.S.; Anderson, J.M.; Ghannoum, M. A Modification of Surface Properties of Biomaterials Influences the Ability of Candida albicans to Form Biofilms. Appl. Environ. Microbiol. 2005, 71, 8795-8801. [CrossRef]

143. Estivill, D.; Arias, A.; Torres-Lana, A.; Carrillo-Muñoz, A.J.; Arévalo, M.P. Biofilm formation by five species of Candida on three clinical materials. J. Microbiol. Methods 2011, 86, 238-242. [CrossRef] [PubMed]

144. Mutluay, M.M.; Oğuz, S.; Ørstavik, D.; Fløystrand, F.; Doğan, A.; Söderling, E.; Närhi, T.; Olsen, I. Experiments on in vivo biofilm formation and in vitro adhesion of Candida species on polysiloxane liners. Gerodontology 2010, 27, 283-291. [CrossRef] [PubMed]

145. Jin, Y.; Samaranayake, L.P.; Samaranayake, Y.; Yip, H.K. Biofilm formation of Candida albicans is variably affected by saliva and dietary sugars. Arch. Oral Biol. 2004, 49, 789-798. [CrossRef] [PubMed] 
146. Choi, H.W.; Shin, J.H.; Jung, S.I.; Park, K.H.; Cho, D.; Kee, S.J.; Shin, M.G.; Suh, S.P.; Ryang, D.W. Species-specific differences in the susceptibilities of biofilms formed by Candida bloodstream isolates to echinocandin antifungals. Antimicrob. Agents Chemother. 2007, 51, 1520-1523. [CrossRef]

147. Valentín, A.; Cantó, E.; Pemán, J.; Martínez, J.P. Voriconazole inhibits biofilm formation in different species of the genus Candida. J. Antimicrob. Chemother. 2012, 67, 2418-2423. [CrossRef] [PubMed]

148. Kucharíková, S.; Tournu, H.; Lagrou, K.; van Dijck, P.; Bujdáková, H. Detailed comparison of Candida albicans and Candida glabrata biofilms under different conditions and their susceptibility to caspofungin and anidulafungin. J. Med. Microbiol. 2011, 60, 1261-1269. [CrossRef] [PubMed]

149. Taff, H.T.; Mitchell, K.F.; Edward, J.A.; Andes, D.R. Mechanisms of Candida biofilm drug resistance. Future Microbiol. 2013, 8, 1325-1337. [CrossRef]

150. Ramage, G.; Bachmann, S.; Patterson, T.F.; Wickes, B.L.; López-ribot, J.L. Investigation of multidrug efflux pumps in relation to fluconazole resistance in Candida albicans biofilms. J. Antimicrob. Chemother. 2002, 49, 973-980. [CrossRef]

151. Vediyappan, G.; Rossignol, T.; D'Enfert, C. Interaction of Candida albicans biofilms with antifungals: Transcriptional response and binding of antifungals to beta-glucans. Antimicrob. Agents Chemother. 2010, 54, 2096-2111. [CrossRef]

152. Rodrigues, C.F.; Silva, S.; Azeredo, J.; Henriques, M. Candida glabrata's recurrent infections: Biofilm formation during Amphotericin B treatment. Lett. Appl. Microbiol. 2016, 63, 77-81. [CrossRef]

153. Johnson, C.J.; Cabezas-Olcoz, J.; Kernien, J.F.; Wang, S.X.; Beebe, D.J.; Huttenlocher, A.; Ansari, H.; Nett, J.E. The Extracellular Matrix of Candida albicans Biofilms Impairs Formation of Neutrophil Extracellular Traps. PLoS Pathog. 2016, 12, 1-23. [CrossRef]

154. Xie, Z.; Thompson, A.; Sobue, T.; Kashleva, H.; Xu, H.; Vasilakos, J.; Dongari-Bagtzoglou, A. Candida albicans biofilms do not trigger reactive oxygen species and evade neutrophil killing. J. Infect. Dis. 2012, 206, 1936-1945. [CrossRef]

155. Lohse, M.B.; Gulati, M.; Johnson, A.D.; Nobile, C.J. Development and regulation of single-and multi-species Candida albicans biofilms. Nat. Rev. Microbiol. 2018, 16, 19-31. [CrossRef]

156. Medzhitov, R. Recognition of microorganisms and activation of the immune response. Nature 2007, 449, 819-826. [CrossRef]

157. Brown, G.D.; Gordon, S. Immune recognition. A new receptor for beta-glucans. Nature 2001, 413, $36-37$. [CrossRef]

158. Li, M.; Chen, Q.; Tang, R.; Shen, Y.; Liu, W. Da The expression of $\beta$-defensin-2, 3 and LL-37 induced by Candida albicans phospholipomannan in human keratinocytes. J. Dermatol. Sci. 2011, 61, 72-75. [CrossRef]

159. Tomalka, J.; Azodi, E.; Narra, H.P.; Patel, K.; O’Neill, S.; Cardwell, C.; Hall, B.A.; Wilson, J.M.; Hise, A.G. $\beta$-Defensin 1 Plays a Role in Acute Mucosal Defense against Candida albicans. J. Immunol. 2015, 194, 1788-1795. [CrossRef]

160. Järvå, M.; Phan, T.K.; Lay, F.T.; Caria, S.; Kvansakul, M.; Hulett, M.D. Human $\beta$-defensin 2 kills Candida albicans through phosphatidylinositol 4,5-bisphosphate-mediated membrane permeabilization. Sci. Adv. 2018, 4, eaat0979. [CrossRef]

161. Hardison, S.E.; Brown, G.D. C-type lectin receptors orchestrate antifungal immunity. Nat. Immunol. 2012, 13, 817-822. [CrossRef]

162. Netea, M.G.; Maródi, L. Innate immune mechanisms for recognition and uptake of Candida species. Trends Immunol. 2010, 31, 346-353. [CrossRef]

163. Cheng, S.-C.; Joosten, L.A.B.; Kullberg, B.-J.; Netea, M.G. Interplay between Candida albicans and the mammalian innate host defense. Infect. Immunity 2012, 80, 1304-1313. [CrossRef]

164. Gilbert, A.S.; Wheeler, R.T.; May, R.C. Fungal Pathogens: Survival and Replication within Macrophages. Cold Spring Harb. Perspect. Med. 2014, 5, a019661. [CrossRef]

165. Free, S.J. Fungal Cell Wall Organization and Biosynthesis; Academic Press: Cambridge, MA, USA, 2013; pp. 33-82.

166. Graus, M.S.; Wester, M.J.; Lowman, D.W.; Williams, D.L.; Kruppa, M.D.; Martinez, C.M.; Young, J.M.; Pappas, H.C.; Lidke, K.A.; Neumann, A.K. Mannan Molecular Substructures Control Nanoscale Glucan Exposure in Candida. Cell Rep. 2018, 24, 2432-2442. [CrossRef] 
167. Ballou, E.R.; Avelar, G.M.; Childers, D.S.; Mackie, J.; Bain, J.M.; Wagener, J.; Kastora, S.L.; Panea, M.D.; Hardison, S.E.; Walker, L.A.; et al. Lactate signalling regulates fungal $\beta$-glucan masking and immune evasion. Nat. Microbiol. 2016, 2, 16238. [CrossRef]

168. Flint, H.J.; Scott, K.P.; Louis, P.; Duncan, S.H. The role of the gut microbiota in nutrition and health. Nat. Rev. Gastroenterol. Hepatol. 2012, 9, 577-589. [CrossRef]

169. Lopes, J.P.; Stylianou, M.; Backman, E.; Holmberg, S.; Jass, J.; Claesson, R.; Urban, C.F. Evasion of Immune Surveillance in Low Oxygen Environments Enhances Candida albicans Virulence. MBio 2018, 9, e2120-18. [CrossRef]

170. Pradhan, A.; Avelar, G.M.; Bain, J.M.; Childers, D.S.; Larcombe, D.E.; Netea, M.G.; Shekhova, E.; Munro, C.A.; Brown, G.D.; Erwig, L.P.; et al. Hypoxia Promotes Immune Evasion by Triggering $\beta$-Glucan Masking on the Candida albicans Cell Surface via Mitochondrial and cAMP-Protein Kinase A Signaling. MBio 2018, 9, e01318-18. [CrossRef]

171. Ene, I.V.; Cheng, S.-C.; Netea, M.G.; Brown, A.J.P. Growth of Candida albicans cells on the physiologically relevant carbon source lactate affects their recognition and phagocytosis by immune cells. Infect. Immunity 2013, 81, 238-248. [CrossRef]

172. Klis, F.M.; de Groot, P.; Hellingwerf, K. Molecular organization of the cell wall of Candida albicans. Med. Mycol. 2001, 39 (Suppl. 1), 1-8. [CrossRef]

173. Netea, M.G.; Brown, G.D.; Kullberg, B.J.; Gow, N.A.R. An integrated model of the recognition of Candida albicans by the innate immune system. Nat. Rev. Microbiol. 2008, 6, 67-78. [CrossRef] [PubMed]

174. Ruiz-Herrera, J.; Victoria Elorza, M.; ValentÃ-n, E.; Sentandreu, R. Molecular organization of the cell wall of Candida albicans and its relation to pathogenicity. FEMS Yeast Res. 2006, 6, 14-29. [CrossRef] [PubMed]

175. Wheeler, R.T.; Kombe, D.; Agarwala, S.D.; Fink, G.R. Dynamic, morphotype-specific Candida albicans beta-glucan exposure during infection and drug treatment. PLoS Pathog. 2008, 4, e1000227. [CrossRef] [PubMed]

176. Hopke, A.; Nicke, N.; Hidu, E.E.; Degani, G.; Popolo, L.; Wheeler, R.T. Neutrophil Attack Triggers Extracellular Trap-Dependent Candida Cell Wall Remodeling and Altered Immune Recognition. PLoS Pathog. 2016, 12, e1005644. [CrossRef] [PubMed]

177. Sherrington, S.L.; Sorsby, E.; Mahtey, N.; Kumwenda, P.; Lenardon, M.D.; Brown, I.; Ballou, E.R.; MacCallum, D.M.; Hall, R.A. Adaptation of Candida albicans to environmental $\mathrm{pH}$ induces cell wall remodelling and enhances innate immune recognition. PLoS Pathog. 2017, 13, e1006403. [CrossRef] [PubMed]

178. Wheeler, R.T.; Fink, G.R. A drug-sensitive genetic network masks fungi from the immune system. PLoS Pathog. 2006, 2, e35. [CrossRef] [PubMed]

179. Hall, R.A.; Bates, S.; Lenardon, M.D.; MacCallum, D.M.; Wagener, J.; Lowman, D.W.; Kruppa, M.D.; Williams, D.L.; Odds, F.C.; Brown, A.J.P.; et al. The Mnn2 Mannosyltransferase Family Modulates Mannoprotein Fibril Length, Immune Recognition and Virulence of Candida albicans. PLoS Pathog. 2013, 9, e1003276. [CrossRef]

180. Rouabhia, M.; Schaller, M.; Corbucci, C.; Vecchiarelli, A.; Prill, S.K.-H.; Giasson, L.; Ernst, J.F. Virulence of the fungal pathogen Candida albicans requires the five isoforms of protein mannosyltransferases. Infect. Immunity 2005, 73, 4571-4580. [CrossRef] [PubMed]

181. West, L.; Lowman, D.W.; Mora-Montes, H.M.; Grubb, S.; Murdoch, C.; Thornhill, M.H.; Gow, N.A.R.; Williams, D.; Haynes, K. Differential virulence of Candida glabrata glycosylation mutants. J. Biol. Chem. 2013, 288, 22006-22018. [CrossRef]

182. Zhang, S.Q.; Zou, Z.; Shen, H.; Shen, S.S.; Miao, Q.; Huang, X.; Liu, W.; Li, L.P.; Chen, S.M.; Yan, L.; et al. Mnn10 Maintains Pathogenicity in Candida albicans by Extending $\alpha-1,6-$ Mannose Backbone to Evade Host Dectin-1 Mediated Antifungal Immunity. PLoS Pathog. 2016, 12, e1005617. [CrossRef]

183. Keppler-Ross, S.; Douglas, L.; Konopka, J.B.; Dean, N. Recognition of Yeast by Murine Macrophages Requires Mannan but Not Glucan. Eukaryot. Cell 2010, 9, 1776-1787. [CrossRef] [PubMed]

184. Chen, S.M.; Shen, H.; Zhang, T.; Huang, X.; Liu, X.Q.; Guo, S.Y.; Zhao, J.J.; Wang, C.F.; Yan, L.; Xu, G.T.; et al. Dectin-1 plays an important role in host defense against systemic Candida glabrata infection. Virulence 2017, 8 , 1643-1656. [CrossRef] [PubMed] 
185. Ifrim, D.C.; Bain, J.M.; Reid, D.M.; Oosting, M.; Verschueren, I.; Gow, N.A.R.; van Krieken, J.H.; Brown, G.D.; Kullberg, B.-J.; Joosten, L.A.B.; et al. Role of Dectin-2 for Host Defense against Systemic Infection with Candida glabrata. Infect. Immunity 2014, 82, 1064-1073. [CrossRef]

186. Jacobsen, I.D.; Brunke, S.; Seider, K.; Schwarzmüller, T.; Firon, A.; d'Enfért, C.; Kuchler, K.; Hube, B. Candida glabrata persistence in mice does not depend on host immunosuppression and is unaffected by fungal amino acid auxotrophy. Infect. Immunity 2010, 78, 1066-1077. [CrossRef]

187. Lambris, J.D.; Ricklin, D.; Geisbrecht, B.V. Complement evasion by human pathogens. Nat. Rev. Microbiol. 2008, 6, 132-142. [CrossRef] [PubMed]

188. Poltermann, S.; Kunert, A.; von der Heide, M.; Eck, R.; Hartmann, A.; Zipfel, P.F. Gpm1p is a factor H-, FHL-1-, and plasminogen-binding surface protein of Candida albicans. J. Biol. Chem. 2007, 282, 37537-37544. [CrossRef]

189. Vogl, G.; Lesiak, I.; Jensen, D.B.; Perkhofer, S.; Eck, R.; Speth, C.; Lass-Flörl, C.; Zipfel, P.F.; Blom, A.M.; Dierich, M.P.; et al. Immune evasion by acquisition of complement inhibitors: The mould Aspergillus binds both factor $\mathrm{H}$ and $\mathrm{C} 4 \mathrm{~b}$ binding protein. Mol. Immunol. 2008, 45, 1485-1493. [CrossRef]

190. Luo, S.; Poltermann, S.; Kunert, A.; Rupp, S.; Zipfel, P.F. Immune evasion of the human pathogenic yeast Candida albicans: Pra1 is a Factor H, FHL-1 and plasminogen binding surface protein. Mol. Immunol. 2009, 47, 541-550. [CrossRef]

191. Kenno, S.; Speth, C.; Rambach, G.; Binder, U.; Chatterjee, S.; Caramalho, R.; Haas, H.; Lass-Flörl, C.; Shaughnessy, J.; Ram, S.; et al. Candida albicans Factor H Binding Molecule Hgt1p-A Low Glucose-Induced Transmembrane Protein Is Trafficked to the Cell Wall and Impairs Phagocytosis and Killing by Human Neutrophils. Front. Microbiol. 2018, 9, 3319. [CrossRef]

192. Staib, F. Serum-proteins as nitrogen source for yeastlike fungi. Sabouraudia 1965, 4, 187-193. [CrossRef] [PubMed]

193. Gropp, K.; Schild, L.; Schindler, S.; Hube, B.; Zipfel, P.F.; Skerka, C. The yeast Candida albicans evades human complement attack by secretion of aspartic proteases. Mol. Immunol. 2009, 47, 465-475. [CrossRef] [PubMed]

194. Meiller, T.F.; Hube, B.; Schild, L.; Shirtliff, M.E.; Scheper, M.A.; Winkler, R.; Ton, A.; Jabra-Rizk, M.A. A novel immune evasion strategy of Candida albicans: Proteolytic cleavage of a salivary antimicrobial peptide. PLoS ONE 2009, 4, e5039. [CrossRef]

195. Svoboda, E.; Schneider, A.E.; Sándor, N.; Lermann, U.; Staib, P.; Kremlitzka, M.; Bajtay, Z.; Barz, D.; Erdei, A.; Józsi, M. Secreted aspartic protease 2 of Candida albicans inactivates factor $\mathrm{H}$ and the macrophage factor H-receptors CR3 (CD11b/CD18) and CR4 (CD11c/CD18). Immunol. Lett. 2015, 168, 13-21. [CrossRef] [PubMed]

196. Hallström, T.; Singh, B.; Kraiczy, P.; Hammerschmidt, S.; Skerka, C.; Zipfel, P.F.; Riesbeck, K. Conserved Patterns of Microbial Immune Escape: Pathogenic Microbes of Diverse Origin Target the Human Terminal Complement Inhibitor Vitronectin via a Single Common Motif. PLoS ONE 2016, 11, e0147709. [CrossRef]

197. Luo, S.; Dasari, P.; Reiher, N.; Hartmann, A.; Jacksch, S.; Wende, E.; Barz, D.; Niemiec, M.J.; Jacobsen, I.; Beyersdorf, N.; et al. The secreted Candida albicans protein Pra1 disrupts host defense by broadly targeting and blocking complement C3 and C3 activation fragments. Mol. Immunol. 2018, 93, 266-277. [CrossRef] [PubMed]

198. Bergfeld, A.; Dasari, P.; Werner, S.; Hughes, T.R.; Song, W.-C.; Hortschansky, P.; Brakhage, A.A.; Hünig, T.; Zipfel, P.F.; Beyersdorf, N. Direct Binding of the $\mathrm{pH}$-Regulated Protein 1 (Pra1) from Candida albicans Inhibits Cytokine Secretion by Mouse CD4+ T Cells. Front. Microbiol. 2017, 8, 844. [CrossRef]

199. Vylkova, S.; Carman, A.J.; Danhof, H.A.; Collette, J.R.; Zhou, H.; Lorenz, M.C. The fungal pathogen Candida albicans autoinduces hyphal morphogenesis by raising extracellular $\mathrm{pH}$. MBio 2011, 2, e00055-11. [CrossRef]

200. Brown, A.J.P.; Brown, G.D.; Netea, M.G.; Gow, N.A.R. Metabolism impacts upon Candida immunogenicity and pathogenicity at multiple levels. Trends Microbiol. 2014, 22, 614-622. [CrossRef]

201. Lorenz, M.C.; Fink, G.R. The glyoxylate cycle is required for fungal virulence. Nature 2001, 412, 83. [CrossRef]

202. Fernández-Arenas, E.; Bleck, C.K.E.; Nombela, C.; Gil, C.; Griffiths, G.; Diez-Orejas, R. Candida albicans actively modulates intracellular membrane trafficking in mouse macrophage phagosomes. Cell. Microbiol. 2009, 11, 560-589. [CrossRef]

203. Kasper, L.; Seider, K.; Gerwien, F.; Allert, S.; Brunke, S.; Schwarzmüller, T.; Ames, L.; Zubiria-Barrera, C.; Mansour, M.K.; Becken, U.; et al. Identification of Candida glabrata genes involved in $\mathrm{pH}$ modulation and modification of the phagosomal environment in macrophages. PLoS ONE 2014, 9, e96015. [CrossRef] 
204. Vylkova, S.; Lorenz, M.C. Modulation of phagosomal pH by Candida albicans promotes hyphal morphogenesis and requires Stp2p, a regulator of amino acid transport. PLoS Pathog. 2014, 10, e1003995. [CrossRef]

205. Rai, M.N.; Balusu, S.; Gorityala, N.; Dandu, L.; Kaur, R. Functional Genomic Analysis of Candida glabrata-Macrophage Interaction: Role of Chromatin Remodeling in Virulence. PLoS Pathog. 2012, 8, e1002863. [CrossRef] [PubMed]

206. Chew, S.Y.; Ho, K.L.; Cheah, Y.K.; Ng, T.S.; Sandai, D.; Brown, A.J.P.; Than, L.T.L. Glyoxylate cycle gene ICL1 is essential for the metabolic flexibility and virulence of Candida glabrata. Sci. Rep. 2019, 9, 2843. [CrossRef] [PubMed]

207. Li, L.; Naseem, S.; Sharma, S.; Konopka, J.B. Flavodoxin-Like Proteins Protect Candida albicans from Oxidative Stress and Promote Virulence. PLoS Pathog. 2015, 11, e1005147. [CrossRef] [PubMed]

208. Wagener, J.; MacCallum, D.M.; Brown, G.D.; Gow, N.A.R. Candida albicans Chitin Increases Arginase-1 Activity in Human Macrophages, with an Impact on Macrophage Antimicrobial Functions. MBio 2017, 8, e01820-16. [CrossRef]

209. Ghosh, S.; Navarathna, D.H.M.L.P.; Roberts, D.D.; Cooper, J.T.; Atkin, A.L.; Petro, T.M.; Nickerson, K.W. Arginine-induced germ tube formation in Candida albicans is essential for escape from murine macrophage line RAW 264.7. Infect. Immunity 2009, 77, 1596-1605. [CrossRef]

210. Danhof, H.A.; Lorenz, M.C. The Candida albicans ATO Gene Family Promotes Neutralization of the Macrophage Phagolysosome. Infect. Immunity 2015, 83, 4416-4426. [CrossRef]

211. Miramón, P.; Lorenz, M.C. The SPS amino acid sensor mediates nutrient acquisition and immune evasion in Candida albicans. Cell. Microbiol. 2016, 18, 1611-1624. [CrossRef]

212. Cuéllar-Cruz, M.; Briones-Martin-del-Campo, M.; Cañas-Villamar, I.; Montalvo-Arredondo, J.; Riego-Ruiz, L.; Castaño, I.; De Las Peñas, A. High Resistance to Oxidative Stress in the Fungal Pathogen Candida glabrata Is Mediated by a Single Catalase, Cta1p, and Is Controlled by the Transcription Factors Yap1p, Skn7p, Msn2p, and Msn4p. Eukaryot. Cell 2008, 7, 814-825. [CrossRef] [PubMed]

213. Fukuda, Y.; Tsai, H.-F.; Myers, T.G.; Bennett, J.E. Transcriptional Profiling of Candida glabrata during Phagocytosis by Neutrophils and in the Infected Mouse Spleen. Infect. Immunity 2013, 81, 1325-1333. [CrossRef]

214. Mahl, C.D.; Behling, C.S.; Hackenhaar, F.S.; de Carvalho e Silva, M.N.; Putti, J.; Salomon, T.B.; Alves, S.H.; Fuentefria, A.; Benfato, M.S. Induction of ROS generation by fluconazole in Candida glabrata: Activation of antioxidant enzymes and oxidative DNA damage. Diagn. Microbiol. Infect. Dis. 2015, 82, 203-208. [CrossRef]

215. Seider, K.; Gerwien, F.; Kasper, L.; Allert, S.; Brunke, S.; Jablonowski, N.; Schwarzmüller, T.; Barz, D.; Rupp, S.; Kuchler, K.; et al. Immune Evasion, Stress Resistance, and Efficient Nutrient Acquisition Are Crucial for Intracellular Survival of Candida glabrata within Macrophages. Eukaryot. Cell 2014, 13, 170-183. [CrossRef]

216. Nevitt, T.; Thiele, D.J. Host Iron Withholding Demands Siderophore Utilization for Candida glabrata to Survive Macrophage Killing. PLoS Pathog. 2011, 7, e1001322. [CrossRef]

217. Srivastava, V.K.; Suneetha, K.J.; Kaur, R. A systematic analysis reveals an essential role for high-affinity iron uptake system, haemolysin and CFEM domain-containing protein in iron homoeostasis and virulence in Candida glabrata. Biochem. J. 2014, 463, 103-114. [CrossRef]

218. Sharma, V.; Purushotham, R.; Kaur, R. The Phosphoinositide 3-Kinase Regulates Retrograde Trafficking of the Iron Permease CgFtr1 and Iron Homeostasis in Candida glabrata. J. Biol. Chem. 2016, 291, 24715-24734. [CrossRef]

219. Wellington, M.; Koselny, K.; Sutterwala, F.S.; Krysan, D.J. Candida albicans triggers NLRP3-mediated pyroptosis in macrophages. Eukaryot. Cell 2014, 13, 329-340. [CrossRef]

220. Miao, E.A.; Rajan, J.V.; Aderem, A. Caspase-1-induced pyroptotic cell death. Immunol. Rev. 2011, 243, 206-214. [CrossRef] [PubMed]

221. Chen, K.W.; Schroder, K. Antimicrobial functions of inflammasomes. Curr. Opin. Microbiol. 2013, 16, 311-318. [CrossRef] [PubMed]

222. Tucey, T.M.; Verma, J.; Harrison, P.F.; Snelgrove, S.L.; Lo, T.L.; Scherer, A.K.; Barugahare, A.A.; Powell, D.R.; Wheeler, R.T.; Hickey, M.J.; et al. Glucose Homeostasis Is Important for Immune Cell Viability during Candida Challenge and Host Survival of Systemic Fungal Infection. Cell Metab. 2018, 27, 988-1006.e7. [CrossRef] [PubMed] 
223. Kasper, L.; König, A.; Koenig, P.-A.; Gresnigt, M.S.; Westman, J.; Drummond, R.A.; Lionakis, M.S.; Groß, O.; Ruland, J.; Naglik, J.R.; et al. The fungal peptide toxin Candidalysin activates the NLRP3 inflammasome and causes cytolysis in mononuclear phagocytes. Nat. Commun. 2018, 9, 4260. [CrossRef]

224. Hise, A.G.; Tomalka, J.; Ganesan, S.; Patel, K.; Hall, B.A.; Brown, G.D.; Fitzgerald, K.A. An Essential Role for the NLRP3 Inflammasome in Host Defense against the Human Fungal Pathogen Candida albicans. Cell Host Microbe 2009, 5, 487-497. [CrossRef]

225. Rogiers, O.; Frising, U.C.; Kucharíková, S.; Jabra-Rizk, M.A.; van Loo, G.; Van Dijck, P.; Wullaert, A. Candidalysin Crucially Contributes to Nlrp3 Inflammasome Activation by Candida albicans Hyphae. MBio 2019, 10, e02221-18. [CrossRef]

226. Hargarten, J.C.; Moore, T.C.; Petro, T.M.; Nickerson, K.W.; Atkin, A.L. Candida albicans Quorum Sensing Molecules Stimulate Mouse Macrophage Migration. Infect. Immunity 2015, 83, 3857-3864. [CrossRef]

227. Brunke, S.; Seider, K.; Fischer, D.; Jacobsen, I.D.; Kasper, L.; Jablonowski, N.; Wartenberg, A.; Bader, O.; Enache-Angoulvant, A.; Schaller, M.; et al. One Small Step for a Yeast-Microevolution within Macrophages Renders Candida glabrata Hypervirulent Due to a Single Point Mutation. PLoS Pathog. 2014, 10, e1004478. [CrossRef]

(C) 2019 by the authors. Licensee MDPI, Basel, Switzerland. This article is an open access article distributed under the terms and conditions of the Creative Commons Attribution (CC BY) license (http://creativecommons.org/licenses/by/4.0/). 